\title{
Interacting effects of Hydrobia ulvae bioturbation and microphytobenthos on the erodibility of mudflat sediments
}

\author{
Francis Orvain ${ }^{1,3, *}$, Pierre-Guy Sauriau ${ }^{1}$, Angélique Sygut ${ }^{1}$, Lucette Joassard ${ }^{1}$, \\ Pierre Le Hir ${ }^{2}$ \\ ${ }^{1}$ CREMA (CNRS-IFREMER UMR 10), Centre de Recherche sur les Ecosystèmes Marins et Aquacoles de L'Houmeau, \\ Place du séminaire BP5, 17137 L'Houmeau, France \\ ${ }^{2}$ IFREMER, Centre de Brest, DEL/EC-TP, BP 70, 29280 Plouzané, France \\ ${ }^{3}$ Present address: LBBM Laboratoire de Biologie et de Biotechnologie Marine, Université de Caen, Esplanade de la Paix, \\ 14032, Caen Cedex, France
}

\begin{abstract}
Microphytobenthos-macrofauna sediment interactions and their effects on sediment erodability were examined in laboratory experiments. Sediment beds were manipulated in a tidal mesocosm to produce diatom mats in exponential or in stationary phases of development after 6,8 or $11 \mathrm{~d}$ of culture. These sediment beds were used in flume experiments to investigate the influence of bioturbation by the gastropod Hydrobia ulvae on both sediment and pigment resuspension as a function of the physiological state of the microphytobenthic mats. In most experiments, only a surface layer was resuspended. A model was used to analyse in detail the contribution of each variable to this surface-layer erosion. Bioturbation was the major factor controlling resuspension, and its extent was influenced by sediment density and the growth stage of the microphytobenthos. The amount and extent of bioturbation is assumed to be influenced by sediment density and chlorophyll a content. Snail bioturbation can, in turn, influence the amount of microalgal resuspension. The quantity of pigment resuspended due to bioturbation increased by a factor of 15 when the diatom mats were in exponential growth stages. However, as the age of the mat increased, the influence of bioturbation on pigment resuspension declined. When the mats became senescent, Type I erosion occurred with erosion rates high enough to obscure any effects of bioturbation. To summarise, we assume that there are 2 causes of microphytobenthos resuspention, depending on the physiological state of the mat: (1) in the exponential phase, bioturbation substantially affects the resuspension of pigments which are present in the surface layer (the biogenic fluff layer) and (2) in the senescent phase, the increase in bed roughness and water content renders the mat fragile, leading to bed erosion.
\end{abstract}

KEY WORDS: Resuspension - Microphytobenthos $\cdot$ Physiological state $\cdot$ Hydrobia ulvae $\cdot$ Model $\cdot$ Erosion $\cdot$ Bioturbation $\cdot$ Sediment

Resale or republication not permitted without written consent of the publisher

\section{INTRODUCTION}

The microalgal community in the water column of coastal ecosystems includes both pelagic microalgae and resuspended benthic microalgae. Knowledge of benthic diatom resuspension is important because benthic microalgae provide a significant food source for heterotrophic populations (Herman et al. 2000,
Sauriau \& Kang 2000). The amount of benthic microalgae in the water column biomass varies both spatially and temporally (Grant et al. 1986, de Jonge \& van Beusekom 1995, Underwood \& Kromkamp 1999, Lucas et al. 2000, 2001, Shimeta et al. 2002). The supply of microphytobenthos to the water column is directly related to sediment resuspension (Lucas et al. 2000), which is affected, at least in part, by wind-induced 
waves (de Jonge \& van Beusekom 1995, Blanchard et al. 2002). Sediment erosion depends on its physical properties (Mehta et al. 1982, Amos et al. 1997) and these can be altered by biological activity (Sutherland et al. 1998a,b, Willows et al. 1998, Austen et al. 1999, Widdows et al. 2000, Andersen 2001). Since the microphytobenthic cells are intimately associated with sediment particles, microalgal resuspension is assumed to be controlled by the same governing factors as sediment resuspension.

Primary and secondary producers are both widely distributed over intertidal mudflats, emphasising their potential effects on erodability of the mudflat surface (Herman et al. 1999). Numerous studies have revealed the contrasting influences of primary producers (i.e. benthic diatoms) and secondary producers (i.e. macrobenthic deposit-feeders) on sediment cohesion. Experimental studies on the control of sediment erodability by microphytobenthic exopolysaccharide (EPS) secretions have reported a positive influence on critical shear stress (Grant et al. 1982, Delgado et al. 1991, Underwood \& Paterson 1993, Sutherland et al. 1998a, Paterson et al. 2000, Yallop et al. 2000, Andersen 2001) and, therefore, a negative effect on erosion rate (Delgado et al. 1991, Sutherland et al. 1998a,b, Paterson et al. 2000, Tolhurst et al. 2000). The effects of depositfeeders and/or facultative suspension-feeders that live in muddy sediments on sediment erodability are difficult to summarise, since their precise effects depend on both the species in question and the habitat (Jumars \& Nowell 1984, Herman et al. 1999). Generally, intensive reworking of the sediment interface by deposit feeders can create a loosened (tracks) and pelletised, organic-rich surface layer (the 'biogenic fluff layer') that is easily resuspended by low velocity tidal currents from the surface (Davis 1993, Blanchard et al. 1997, Willows et al. 1998, Andersen 2001, Orvain et al. 2003b). More precisely, the biogenic fluff layer is a complex 3-dimensional landscape including tracks, faecal pellets, pseudofaeces and mucus, which are produced through feeding and locomotion activities of macrofauna. This biogenic fluff layer is disconnected from the sediment matrix and it has its own specific behaviour in terms of erodability. The use of classical equations for bed erosion (Type I or II, see Amos et al. 1997) cannot account for erosion of the biogenic fluff layer related to bioturbation. This conclusion is confirmed by the requirement of other equations for a full reproduction of resuspension results obtained by some biologists (Willows et al. 1998, Orvain et al. 2003b) who have investigated the influence of deposit-feeders on sediment erodability. The sequential resuspension of the surface biogenic layer and the sediment bed suggests that the precise role of microphytobenthos in sediment erosion remains unclear. Investigating the influence of interactions between microphytobenthos and macrofauna on sediment erosion requires a distinction between the effects of microphytobenthos on (1) biogenic fluff layer erosion and (2) bed erosion.

Austen et al. (1999) have studied how the erodability of mudflats in the Wadden Sea (Denmark) is affected by the bioturbation of the common mud snail Hydrobia ulvae and the integrity of the microphytobenthic mats. They concluded that the primary influence on sediment erodability is the integrity of the microphytobenthic mat, but that grazing by $H$. ulvae limits the extent of this influence. Since diatoms make up the main part of the snail's diet (Jensen \& Siegismund 1980, Herman et al. 2000), the primary influence of benthic organisms on sediment erodability was attributed to the diatom mat that was in turn regulated by grazing activities. This conclusion also suggests that there is no direct influence of snails on erodability when there is no biofilm. Nevertheless, Andersen (2001) has shown that neither sediment chl a concentrations nor sediment water contents govern erosion rates at low shear stress (ca. 0.5 Pa) on the Danish mudflats, but that measured erosion rates correlate with the amount of $H$. ulvae pelletisation. Laboratory flume experiments performed on cohesive sediments with very low diatom densities (i.e. in the absence of a mat) have shown that $H$. ulvae bioturbation activities can destabilise the sedimentary structure (Blanchard et al. 1997, Andersen et al. 2002, Orvain et al. 2003b). These findings suggest that interacting effects of macrofauna bioturbation and microphytobenthos, such as the effects of the grazing and bioturbation activities of $H$. ulvae on the integrity of the mat layer, or the development of a biogenic layer by macrofauna bioturbation in the presence of a microphytobenthic mat, are not yet well understood.

The presence of a surface biogenic layer generated through bioturbation also affects the resuspension of protists and, especially, microphytobenthic species. Blanchard et al. (1997) found that bioturbation responsible for differing erosion thresholds between benthic diatoms and bacteria. They identified a biogenic fluff layer that originates from the sediment in response to bioturbation activities. Wiltshire et al. (1998) demonstrated that 'pigments derived from [...] surface biofilms appear in the water column before the general failure of the bed'. In field experiments, Shimeta et al. (2002) identified a sequential resuspension among heterotrophic and autotrophic protistan groups under tidal flow. In this case, the fluff layer is not bound to the sediment and refers to phytodetritus that sinks out of the water column onto the sea bed. Generally, the term fluff layer is a concept that refers to a surface layer, which is constituted by loose aggregates that have specific eroding behaviour differing from that of the underlying sediment bed. However, the fluff layer can 
have different origins: (1) when sediment and phytodetritus drop out of the water column and sink into the sea bed (Beaulieu 2002, Shimeta et al. 2002); and (2) when the sediment bed is destabilised due to the process of bioturbation, producing tracks, mucus-rich biodeposits and loosened aggregates (Blanchard et al. 1997, Willows et al. 1998, Orvain et al. 2003b). Despite these different origins, the fluff layer always has a higher fraction of microalgal cells compared to the sediment bed at a greater depth. This phenomena is due to the localisation of this layer at the sediment surface, where sinking phytodetritus and upward migrating microphytobenthos concentrate. In the present study, we refer to a 'biogenic fluff layer' (due to the process of bioturbation) to avoid any confusion with the 'fluff layer' that originates from sinking material.

Bioturbation by macrofauna and/or meiofauna contributes to the formation of a fluff layer comprising a higher proportion of microalgal cells, which are concentrated at the surface. The precise role of macrofauna bioturbation in the sequential resuspension of protists remains unclear. The connections between the sequential resuspension of the biogenic fluff layer and bed erosions, and the sequential resuspension of protists must be clarified.

This investigation was designed to quantify how $\mathrm{Hy}$ drobia ulvae bioturbation affects the erodability of both the biological and sedimentological components of mudflat sediments. Our objectives were 2-fold: (1) to measure the influence of bioturbation on both sediment and pigment erosion of a cohesive sediment bed that was covered by living diatom mats; and (2) to determine whether the age of microphytobenthic mats affects how bioturbation contributes to sediment and pigment resuspension. We investigated the influence of $H$. ulvae bioturbation on sediment stability using pre-treated and homogenised mudflat sediments that had been inoculated with active diatom populations in mesocosm and flume experiments. Microphytobenthic mats of different ages (after 6,8 and $11 \mathrm{~d}$ of growth) were allowed to develop on the inoculated sediments. The physiological state of diatom mats is known to depend on the mat age; 6 and $8 \mathrm{~d}$ cultured sediments show an exponential phase of growth while $11 \mathrm{~d}$ cultured sediments show a stationary phase of growth (Sutherland et al. 1998a, Orvain et al. 2003a). We hypothesise that both exponential and stationary phases are likely to be found on the field, the former being characterised by a series of oscillating chl $a$ concentrations due to net increase during daytime exposure (Blanchard et al. 2001), and the latter being characterised by older, established biofilms, which can occasionally occur in natural conditions, as reported by van Duyl et al. (2000) and Yallop et al. (1994).

A 1-dimensional vertical (1DV) model has been developed to simulate the temporal succession of bio- genic layer and sediment bed erosion. Orvain et al. (2003b) used flume data to describe and model the interactions between both erosion phases. A streamlined version of the model also exists where only biogenic fluff layer erosion takes place. We tested the model with our new data in order to examine how bioturbation, sediment and microphytobenthos interact to control resuspension of the biogenic layer. The parameterisation of the model using new data considering interacting effects of both macrofauna and microphytobenthos on sediment resuspension is essential to better understand and model benthic interactions.

\section{MATERIALS AND METHODS}

Sediment preparation. Mudflat sediments were collected from the Brouage mudflat in Marennes-Oléron Bay (SW France). Sediments were collected from 10 to $20 \mathrm{~cm}$ below the surface in order to avoid contamination with active diatoms in our experiments. The mud was sieved to $<1 \mathrm{~mm}$ to remove the macrofauna without adding water, and then homogenised regularly during a storage period of $2 \mathrm{mo}$ in darkness at $10^{\circ} \mathrm{C}$. This homogenised, sieved sediment was our stock mud that was used in all the experiments. The $<63 \mu \mathrm{m}$ fraction accounted for $92 \%$, by dry weight, of the homogenised stock sediment (see Galois et al. 2000 for a detailed description). The grain size averaged 1 to $6 \mu \mathrm{m}$ (Gouleau et al. 2000). Surficial sediments were also collected and sieved to retain Hydrobia ulvae individuals which were cultivated in the laboratory during the same period of 2 mo.

Preliminary tests and experimental design. Two factors were tested: (1) the stages of development of the microphytobenthic mat on the sediment surface; and (2) the population density of Hydrobia ulvae grazing on the sediment surface. Preliminary experiments within the mesocosm (Orvain et al. 2003a) demonstrated that microphytobenthic mat cultures could be replicated and 3 successive growth phases were identified:

(i) a lag phase (ca. 0 to $5 \mathrm{~d}$ ), during which the microalgae adapted to experimental tidal and diurnal forcings;

(ii) a logarithmic phase (5 to $9 \mathrm{~d}$ ), during which microalgae were photosynthetically active and formed a mat;

(iii) a stationary/senescent phase (10 to $12 \mathrm{~d}$ ), when the biomass reached equilibrium in the mesocosm.

In accordance with these results, we chose to use diatom-enriched sediments after 6, 8 and $11 \mathrm{~d}$ of mat development in the mesocosm.

Control experiments were performed with the homogenised stock sediments, but without the added dia- 
tom cultures (although, because we used natural sediments, they did contain degraded products of chl a). In addition, we expected that the use of natural sediments, no matter how well homogenised, would increase the variance of measured parameters, since it is not possible to obtain true replicates in flume experiments. However, sediment water content reproduced so poorly in the preliminary experiments that we prepared 2 types of control experimental conditions: Control 1, in which the mud was placed into the flume immediately after filling the test trays (compact sediments); and Control 2, in which, after being loaded into the test trays, the mud was allowed to equilibrate submerged in a circulating seawater bath for $90 \mathrm{~d}$ (waterequilibrated sediments) prior to being inserted into the flume. Thus, changes in the water saturation profiles that developed in the sediments as a result of experimental manipulation, and in the absence of snail bioturbation and diatom growth, could be measured and compared.

One experimental series was performed with 10000 snails $\mathrm{m}^{-2}$ and another was performed without snails for the 3 mat ages (that is, after 6,8 or $11 \mathrm{~d}$ of diatom culture). Two replicated experiments were performed for cultivated sediments. Only 1 experimental run each, with densities from 0 to 10000 snails $\mathrm{m}^{-2}$, was performed for Control 1 and Control 2. Thus, including replicates, 16 flume experiments were completed.

Macrofauna was removed from the initial stock of mud, but meiofauna was still present in the experimental sediment: foraminifera and nematoda were not abundant, with a total density equal to $84.925 \pm 24.921$ SD ind. $\mathrm{m}^{-2}$, which could exert a limited bioturbation effect. Even if such an effect occurred in experiments, it was assumed to be constant over the entire experimental set and represent a part of the ambient signal in control experiments without macrofauna.

Experimental conditions in the mesocosm. Trays (length: $90 \mathrm{~cm}$; width: $40 \mathrm{~cm}$; height: $20 \mathrm{~cm}$ ) were loaded with the homogenised sediment and enriched with cultures of microphytobenthic algae (Orvain et al. 2003a). These trays were installed into a tank connected to a recirculating filtered seawater system (Orvain et al. 2003a). One $6 \mathrm{~h}$ long daylight and air exposure period was reproduced in the mesocosm between 08:00 and 14:00 h every day; the photosynthetically active radiation (PAR) was $140 \mu \mathrm{mol} \mathrm{m} \mathrm{m}^{-2} \mathrm{~s}^{-1}$ during these simulated diurnal low tides. Otherwise, the sediments remained in the dark and flooded with circulating seawater. Individual trays were removed from the tank and placed into the experimental section of the laboratory flume after 6,8 or $11 \mathrm{~d}$ of growth in the mesocosm.

Flume experiments. Bed shear stresses in the flume were estimated once using current velocity profiles (see Orvain et al. 2003b for a detailed description). An ultrasonic velocity meter (Minilab system) was used to measure 8 current profiles for 8 different propeller speeds and for each profile, and 17 velocity measurements were taken. The flume set-up produced a stable and unidirectional flow, assuring reproducibility of flow conditions. We obtained logarithmic profiles and we used the so-called universal von Karman-Prandtl 'law of the wall' relationship within the logarithmic layer:

$$
u(z)=\frac{u^{*}}{k} \ln \left(\frac{z}{z_{0}}\right)
$$

where, $u(z)$ is the mean horizontal velocity at height $z\left(\mathrm{~m} \mathrm{~s}^{-1}\right), u^{*}$ is the friction velocity $\left(\mathrm{m} \mathrm{s}^{-1}\right), k$ is von Karman's constant $(0.41)$ and $z_{0}$ is the roughness length $(\mathrm{m})$. The shear velocity and the roughness length were deduced from the logarithmic part of the flow profile, where the plot of $u(z)$ versus $\ln (z)$ gives a linear relationship with a slope of $\mathrm{k} / \mathrm{u}^{*}$ and an intercept at $\ln \left(z_{0}\right)$. The top of the logarithmic layer $\left(h_{\text {log }}\right)$ was always chosen as $20 \%$ of the water depth $(15 \mathrm{~cm})$, since this value allowed the best correlation in the determination of $u^{*}$. The infinite velocity $\left(u_{\infty}\right)$ was determined by averaging velocities measured above this distance from the bed:

$$
u_{\infty}=\int_{h_{\log }}^{\delta} u d z
$$

We obtained the relationship between $u^{*}$ and $u_{\infty}$ :

$$
u^{*}=6.8 \times 10^{-2} \times u_{\infty} \quad\left(\mathrm{r}^{2}=0.96\right)
$$

Bed shear stress $\left(\tau_{\mathrm{f}}\right)$ was calculated from friction velocity according to:

$$
\tau_{\mathrm{f}}(\mathrm{Pa})=\rho \times u^{* 2}
$$

where $\rho=$ water density $\left(1020 \mathrm{~kg} \mathrm{~m}^{-3}\right.$ for the seawater used in our experiments).

Differences in bed roughness between flume experiments were limited by avoiding edge effects and by the use of the same initial stock of mud in each case. It was desirable to minimise edge effects, especially where the sediment adjoined the upstream side of the flume base once transferred into the flume. To limit these effects, the tray was filled with the prepared mud prior to the addition of the microphytobenthos culture, and the bed surface was delicately shaped to further adjoin the flume bottom on both the downstream and upstream edges. Trays were transferred from the mesocosm into the test section of the benthic flume at the end of the microphytobenthos culture (precisely at the beginning of the last low-tide period). Once the trays of sediment had been placed in the flume test section, 10000 snails $\mathrm{m}^{-2}$ were evenly distributed on the test bed (walled to prevent the snails from escaping) and the sediment was 
subjected to a $6 \mathrm{~h}$ exposure period under artificial light $\left(140 \mu \mathrm{mol} \mathrm{m} \mathrm{m}^{-2} \mathrm{~s}^{-1}\right)$, as in the mesocosm (Orvain et al. 2003a). The duration of the bioturbation period was thus $6 \mathrm{~h}$, during which time snails crawled on the sediment bed and produced a fluff layer comprising tracks and faecal pellets. Walls were then removed from the test bed and the flume was filled until the water column height reached $0.15 \mathrm{~m}$ without disturbing the sediment surface. The fluff layer was not washed away due to filling. Sediments without Hydrobia ulvae were treated the same way. Resuspension of the sediment and microalgae from the test bed was then quantified in response to stepwise increases in bed shear stress (12 steps between 0.07 and $1.60 \mathrm{~Pa}_{\text {; corresponding cur- }}$ rent speed range was 0.12 to $0.60 \mathrm{~m} \mathrm{~s}^{-1}$ for the test bed roughness). Each step lasted 20 min. Turbidity, expressed as a concentration of suspended matter (SPM in $\mathrm{kg} \mathrm{m}^{-3}$ ), in the flume was monitored at $15 \mathrm{~s}$ intervals using an optical back-scattering sensor (OBS) that was placed $1 \mathrm{~m}$ downstream of test section and $10 \mathrm{~cm}$ above the flume floor (preliminary tests were performed to check water column homogeneity at this location and to verify the assumption that no deposition occurred in the flume during experiments). At the end of each $20 \mathrm{~min}$ step, a turbidity calibration was conducted on $5 \mathrm{dm}^{3}$ water samples from the flume. Duplicate water subsamples $\left(1 \mathrm{dm}^{3}\right)$ from the $5 \mathrm{dm}^{3}$ sample were filtered immediately through pre-weighed Whatman GF/C filters; the filters were then dried at $50^{\circ} \mathrm{C}$ for $3 \mathrm{~d}$ and reweighed. Thus, each experiment had 24 suspended matter measurements.

In each experiment, OBS time series were calibrated from the measured SPM values of the specified experimental run $\left(\mathrm{r}^{2}=0.925, F_{31,346}=138.4, \mathrm{p}<0.001 \mathrm{n}=384\right.$, computed from all 16 experiments). Resuspension data were converted into sediment mass eroded per unit area ( $M$ in $\mathrm{kg} \mathrm{m}^{-2}$ ) according to the formula:

$$
M=\operatorname{SPM} V / S
$$

where $V$ is the flume volume $\left(\mathrm{m}^{3}\right)$ and $S$ is the test section surface $\left(\mathrm{m}^{2}\right)$. The erosion threshold $\left(u^{*}{ }_{\mathrm{cr}}\right)$ was determined by using the plot of SPM versus bed shear velocity $\left(u^{*}\right)$. The best-fit regression lines of the data were found using a semi-logarithmic equation, SPM = $\mathrm{A}+\mathrm{Blog}_{10}\left(u^{*}\right)$, and the solution of the intercept with the baseline, SPM $=0$, was calculated.

At each shear stress tested, 2 additional water subsamples $\left(1 \mathrm{dm}^{3}\right)$ from the $5 \mathrm{dm}^{3}$ sample were filtered immediately through pre-ashed $\left(450^{\circ} \mathrm{C}\right)$ Whatman GF/C filters in order to measure the suspended chl a and phaeopigment concentrations. The same operating procedure as for the sediments was used, and this analysis is described in the subsequent section.

It was not possible to directly measure the sediment characteristics in the manipulated trays because re- moval of cores would affect bed roughness and, thus, resuspension results. Therefore, 2 additional small trays were prepared in the same way as the larger trays to measure sediment parameters (for diatomcultured sediments as well as the control sediments). Sediment cores $(n=2)$ were taken at the end of the artificial low-tide period from each tray. Depth profiles of sediment water content ( $g$ water/g dry sediment $x$ 100) and pigment contents (in $\mu \mathrm{g} \mathrm{g}^{-1}$ ) were measured in separate unfrozen cores, sectioned at intervals of: $0-2,2-4,4-6,6-8,8-10,10-15$ and 15-20 mm. EPS concentrations were measured in surface sections (0-5 and 5-10 mm) of 2 other cores that were taken from the same trays. Water content (g water/g dry sediment $\times 100$ ) was estimated from the water-mass loss after drying at $60^{\circ} \mathrm{C}$ for $3 \mathrm{~d}$. A salt correction was applied using an interstitial water salinity of $31 \mathrm{psu}$, which was the salinity of the overlying seawater in the flume. The sediment dry density (i.e. $\rho_{\mathrm{d}}$ in $\mathrm{kg} \mathrm{m}^{-3}$ ) was calculated using the following formula:

$$
\rho_{\mathrm{d}}\left(\mathrm{kg} \mathrm{m}^{-3}\right)=\frac{\rho_{\mathrm{s}} \cdot 1000}{w / 100 \cdot \rho_{\mathrm{s}}+1000}
$$

where $\rho_{\mathrm{s}}$ is the average grain density $\left(2650 \mathrm{~kg} \mathrm{~m}^{-3}\right)$ and $w$ is the water content.

Although we systematically measured sedimentological and biological parameters in each flume, the use of natural sediments made the existence of slight variations between the individual sediment beds unavoidable. Through the use of controls, we tried to establish some limits to this natural variability. Additional details on the methodology for sediment preparation and enrichment in microphytobenthos are described in Orvain et al. (2003a).

Pigment and carbohydrate analyses. The microphytobenthic biomass was assessed by measuring chl a content in the sediments. The chloropigments were extracted from $100 \mathrm{mg}$ freeze-dried sediment subsamples with $80 \%$ methanol for $1 \mathrm{~h}$ at $4^{\circ} \mathrm{C}$ in the dark. After centrifugation, the supernatant fluorescence was measured before and after acidification $\left(10 \mathrm{~mm}^{3} 0.3 \mathrm{M}\right.$ $\left.\mathrm{HCl} \mathrm{mm}^{-3} \mathrm{MeOH}\right)$. Total chl $a$ and phaeopigments were calculated from the fluorescence as g g DW ${ }^{-1}$ (dry weight), according to Lorenzen's (1967) equations.

Carbohydrates are operationally divided into 2 major types: low molecular weight (LMW) sugar unit molecules (alcohol soluble) and high molecular weight (HMW) polymeric molecules (alcohol insoluble) (Underwood et al. 1995). To extract the HMW carbohydrates, which are the best index to differentiate exponential and stationary phases of growth (Orvain et al. 2003a), $500 \mathrm{mg}$ of freeze-dried sediment was extracted with $5 \mathrm{~cm}^{3}$ of distilled water for $1 \mathrm{~h}$ at $30^{\circ} \mathrm{C}$, under continuous agitation. The samples were centrifuged for 
$10 \mathrm{~min}$ at a relative centrifugal force of $2000 \times g$. To separate the LMW and HMW carbohydrate fractions, two $1 \mathrm{~cm}^{3}$ aliquots of the resulting supernatant were evaporated at $60^{\circ} \mathrm{C}$, under a constant flow of nitrogen gas. The residue was dissolved in $1 \mathrm{~cm}^{3}$ of distilled water and then mixed with $4 \mathrm{~cm}^{3}$ of pure ethanol. This mixture was left overnight at $4^{\circ} \mathrm{C}$ to precipitate, and then centrifuged $(15 \mathrm{~min}, 4000 \times g)$ to pellet the precipitated polymeric fraction. The ethanol supernatant solution was separated from the pellet and was evaporated at $60^{\circ} \mathrm{C}$ under a flow of nitrogen, centrifuged, and then the resulting pellet was dissolved in $1 \mathrm{~cm}^{3}$ of distilled water to measure soluble EPS. The ethanolinsoluble material (i.e. the pellet resulting from the initial precipitation) was dissolved in $1 \mathrm{~cm}^{3}$ of distilled water to measure HMW carbohydrates. LMW and HMW carbohydrates were measured by the phenolsulphuric acid assay (Dubois et al. 1956) using standards of D-glucose dissolved in $\mathrm{H}_{2} \mathrm{O}$.

Statistical analyses. All data were initially tested for homoscedasticity prior to statistic analysis using the Bartlett's test. Heteroscedastic data were $\log _{10}(N+1)$ transformed; otherwise, the non-parametric test of Kruskal-Wallis was used. All analyses were performed with the MINITAB package release 10.2.

Concerning sediment data, a 1-way ANOVA could be applied to the results from the test of the 'culture age' factor, when superficial values were compared. A similar 1-way ANOVA could be used when 'depth' was the single factor tested. However, the combination of both factors (i.e 'culture age' and 'depth') could not fit a 2-way test with replications due to spatial correlation. Indeed, the depth of the same core was measured repeatedly and data from depth profiles (of univariate data like chl $a$, EPS and water contents) are spatially correlated (von Ende 1993). Vertical profiles in the sediment were tested by 2-way, repeated-measures ANOVA (Multiway ANOVA). Depth in the sediment was the repeated factor and culture age was the second.

Concerning the analysis of flume experiment data, the results from the test of the 'culture age', 'bioturbation' and 'shear velocity' factors are organised according to a partially hierarchical design with 3 fixed factors: 'culture age' (control and 3 ages), 'bioturbation' (presence or absence) and 'shear velocity' (12 shear velocities). The first factors were fully crossed and organised as a 2-way design with replications. Two replicates of this complete $4 \times 2$ factorial experiment were conducted in a random sequence of 16 flume experiments. Since shear velocities were increased step-bystep within each flume experiment, the shear velocity factor was therefore nested to the flume experiment factor. This design was previously used by Blanchard et al. (1997) to analyse similar flume experiments, and can be compared to a complex split-plot design (see Potvin 1993 for a detailed description) which involved 2 between-flume-experiments crossed-factors and a within flume-experiment factor.

\section{RESULTS}

\section{Depth distribution of pigments and water content}

The homogenised stock sediment contained $5 \mu \mathrm{g}$ $\mathrm{gDW}^{-1}$ of chl $a$ and $6 \mu \mathrm{g} \mathrm{gDW}{ }^{-1}$ of phaeopigments. The pigment content values for Control 1 conditions (Fig. 1d) did not vary significantly from the values measured in the stock (1-way ANOVA, $F_{6,33}=2.3, \mathrm{p}=$ 0.058). Under Control 2 conditions, the surface chl $a$ and phaeopigment contents (Phaeo) $(0-2 \mathrm{~mm}$ section) decreased during the $90 \mathrm{~d}$ ageing period relative to the deeper sediments (Fig. 1e); these contents changed significantly with depth (Kruskal-Wallis test, $H=24.19$, $\mathrm{df}=6, \mathrm{p}=0.001$ ). Photo-oxidative processes were responsible for $\mathrm{chl} a$ and phaeopigment degradation at the surface during the $90 \mathrm{~d}$ treatment (Bianchi et al. 1988).

Pigment content varied depending on the age of the culture (1-way ANOVA of 'culture age' factor, $F_{2,21}=$ $22.66, \mathrm{p}<0.001)$. The $[\text { Phaeo:Chla] }]_{\text {SEDIMENT }}$ ratios were higher under both control conditions as compared to the fresh diatom cultures in the enriched sediments (Table 1). Algal content increased exponentially with culture age (chl $a$ in Table 1) and the pigment contents decreased as sediment depth increased (Multiway ANOVA, $F_{4,40}=8.66, \mathrm{p}<0.001$, Fig. $1 \mathrm{a}-\mathrm{c}$ ). The longer the diatom culture was allowed to grow, the more pronounced the decrease in pigment content with depth became. The sharp increase in surface pigment contents was largely due to higher chl a content, and thus the [Phaeo:Chla $]_{\text {SEDIMENT }}$ ratios also significantly decreased with culture age (1-way ANOVA of 'culture age' factor, $F_{2,21}=9.25, \mathrm{p}<0.001$, Table 1 ).

The EPS content was $0.17 \mathrm{mg} \mathrm{gDW}^{-1}$ in the homogenised stock sediment. Surface measurements did not significantly increase after 6 or $8 \mathrm{~d}$ of culture (1-way ANOVA on data gathered after 6 and $8 \mathrm{~d}$ of culture, $F_{1,13}=3.92, \mathrm{p}=0.07$ ). However, considering all the data (including after $11 \mathrm{~d}$ ) in the same statistical test showed a significant increase with culture age $\left(F_{2,17}=\right.$ $3.90, p=0.04)$. Sediments thus had a significantly higher EPS content after $11 \mathrm{~d}$ of diatom growth in the experimental system (Table 1). No significant differences in EPS content existed between the 0-5 $\mathrm{mm}$ and 5-10 depth sections (Multiway ANOVA, $F_{4,32}=2.03$, $\mathrm{p}=0.114)$.

The water content was about $170 \%$ in the stock sediment, and there was no significant difference between 

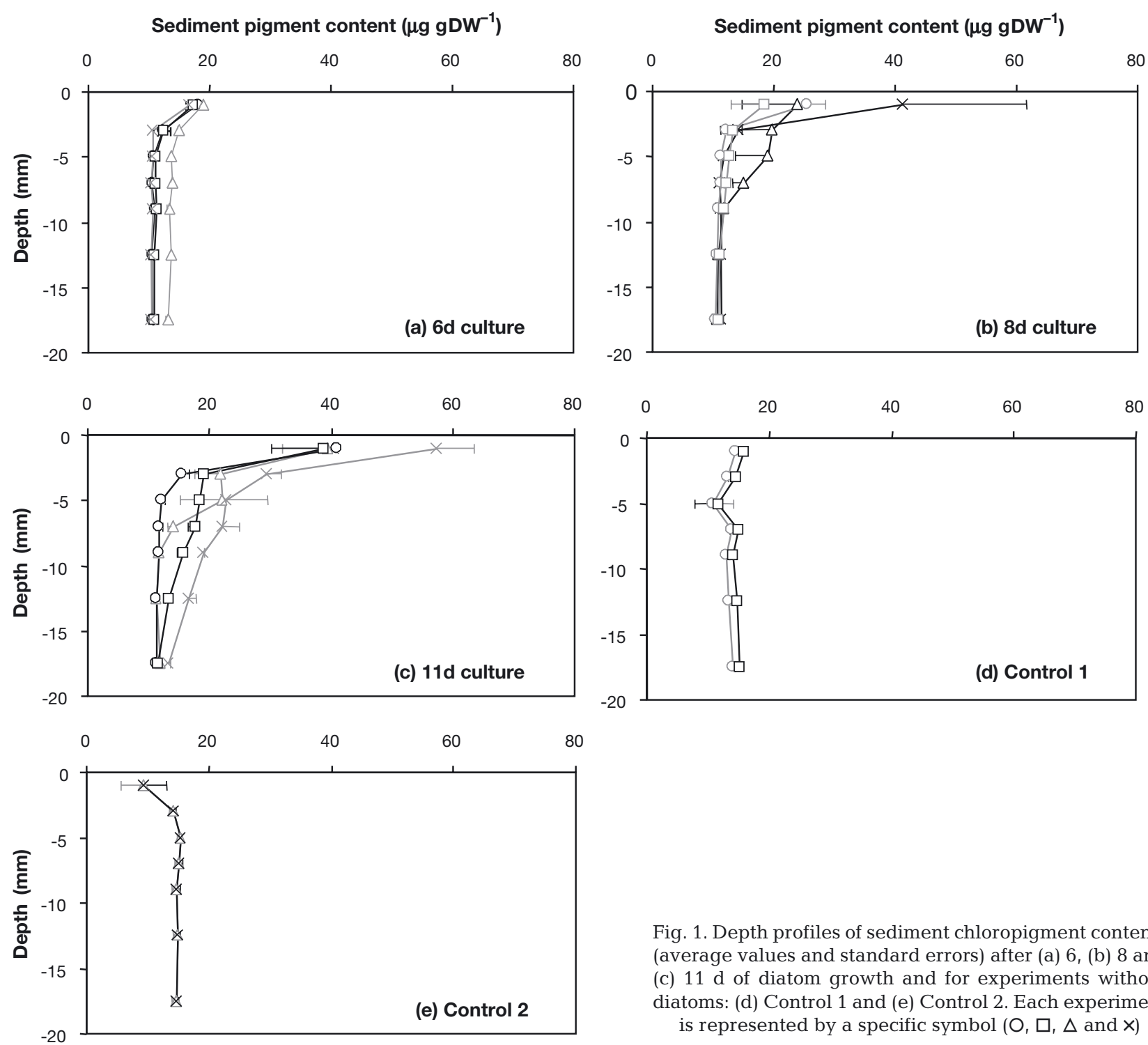

Fig. 1. Depth profiles of sediment chloropigment contents (average values and standard errors) after (a) 6, (b) 8 and (c) $11 \mathrm{~d}$ of diatom growth and for experiments without diatoms: (d) Control 1 and (e) Control 2. Each experiment is represented by a specific symbol $(O, \square, \Delta$ and $X)$

Table 1. Sediment characteristics for the 3 periods of diatom growth and the 2 control types. Averaged values with standard errors are given. EPS: exopolysaccharide

\begin{tabular}{|c|c|c|c|c|c|c|}
\hline Conditions & $\begin{array}{l}\text { Culture } \\
\text { age (d) }\end{array}$ & $\begin{array}{c}\text { EPS } \\
\left(\mathrm{mg} \mathrm{gDW}^{-1}\right)\end{array}$ & $\begin{array}{c}\text { Chl } a \\
\left(\mu \mathrm{g} \mathrm{gDW} W^{-1}\right)\end{array}$ & $\begin{array}{c}\text { Phaeopigments } \\
\left(\mu \mathrm{g} \mathrm{gDW} \mathrm{DW}^{-1}\right)\end{array}$ & {$[\text { Phaeo:Chla }]_{\text {SEDIMENT }}$} & $\begin{array}{c}\text { Water content } \\
(\%)\end{array}$ \\
\hline Enriched in diatoms & $\begin{array}{r}6 \\
8 \\
11\end{array}$ & $\begin{array}{l}0.16 \pm 0.02 \\
0.13 \pm 0.03 \\
0.19 \pm 0.01\end{array}$ & $\begin{array}{r}8.93 \pm 1.49 \\
17.08 \pm 8.59 \\
31.16 \pm 8.59\end{array}$ & $\begin{array}{r}8.95 \pm 2.39 \\
10.33 \pm 1.27 \\
12.96 \pm 0.74\end{array}$ & $\begin{array}{l}1.06 \pm 0.52 \\
0.70 \pm 0.27 \\
0.43 \pm 0.08\end{array}$ & $\begin{array}{l}179 \pm 7 \\
218 \pm 27 \\
212 \pm 13\end{array}$ \\
\hline Without diatoms & $\begin{array}{r}90 \\
0\end{array}$ & $\begin{array}{c}- \\
0.17\end{array}$ & $\begin{array}{l}5.09 \pm 0.37 \\
5.84 \pm 0.07\end{array}$ & $\begin{array}{l}6.14 \pm 0.42 \\
6.88 \pm 0.44\end{array}$ & $\begin{array}{l}1.21 \pm 0.03 \\
1.18 \pm 0.08\end{array}$ & $\begin{array}{l}259 \pm 9 \\
174 \pm 6\end{array}$ \\
\hline
\end{tabular}

the bulk value and the values measured over depth for Control 1 conditions (Fig. 2d, ANOVA, $F_{6,35}=0.23, \mathrm{p}=$ 0.964). The depth profiles from the Control 2 conditions were the most heterogeneous (Fig. 2e, ANOVA,
$\left.F_{6,35}=196.23, \mathrm{p}<0.001\right)$. Depth profiles of the water content from test beds with active diatom cultures (Figs. 2a-c) are intermediate between Controls 1 and 2. In the upper $4 \mathrm{~mm}$ of the test beds, water content 


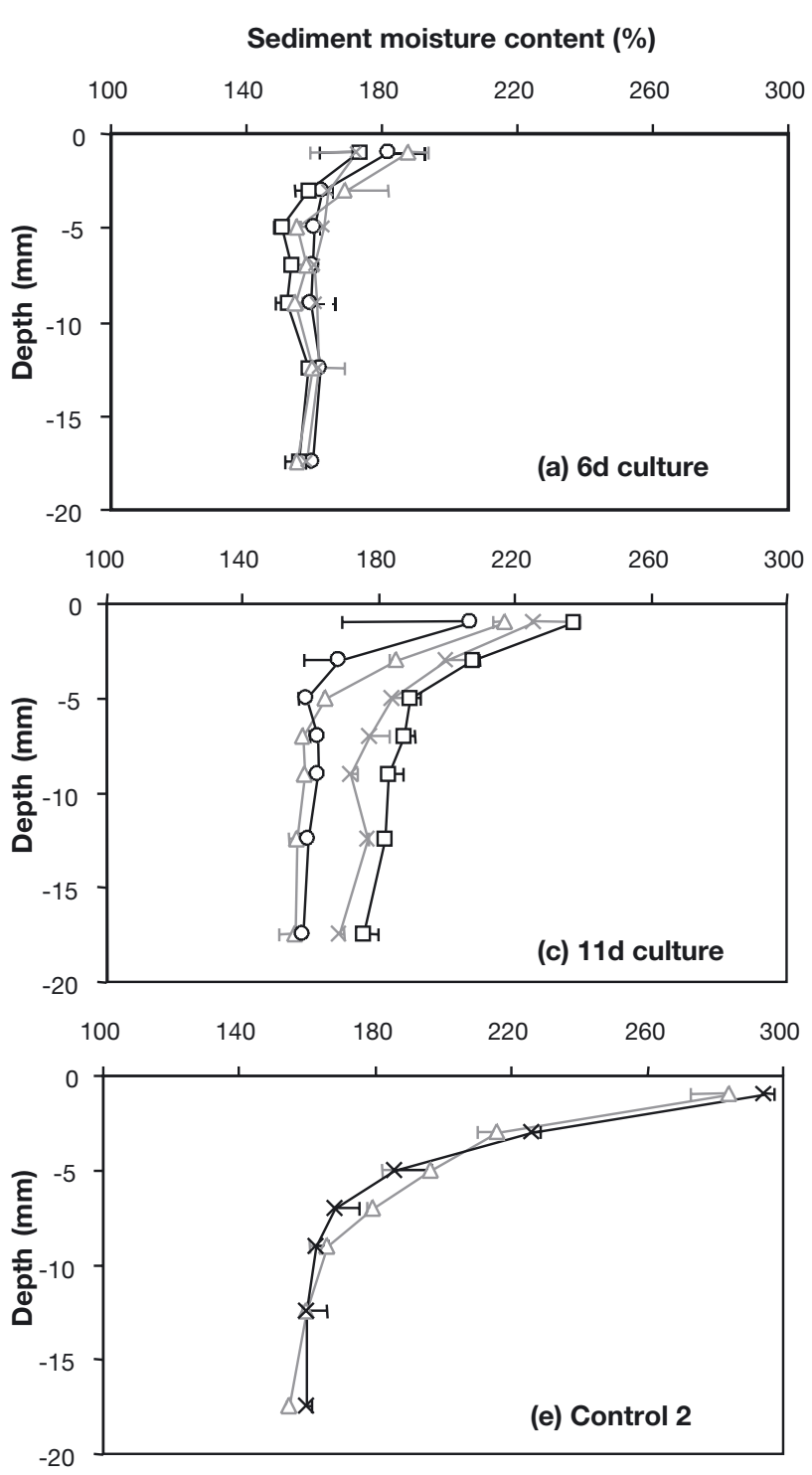

clearly changed over time (Fig. 2a-c) for the 0-2 mm section (ANOVA of 'culture age' factor, $F_{2,19}=14.28$, $\mathrm{p}<0.001$ ) and the $2-4 \mathrm{~mm}$ section (ANOVA, $F_{2,19}=$ 9.18, $\mathrm{p}=0.002)$. There was also a difference due to depth (Multiway ANOVA, $F_{4,36}=5.29, p=0.002$ ). Similar to $\mathrm{chl} a$, the variability in water content increased during treatment (see standard errors in Table 1, Fig. 2a-c). This is confirmed by a high level of correlation between sediment water and chl a contents when considering all the data by depth from the experiments with active diatom cultures $\left(r=0.72, F_{1,75}=118.7\right.$, $\mathrm{p}<0.001$ ).

The scatter increased for surface water and chl a contents (data from 0-2 mm layer; Figs. 1 \& 2, Table 1) during treatment. The 6 d cultured sediments had similar results to Control 1 in terms of water content,

\section{Sediment moisture content (\%)}

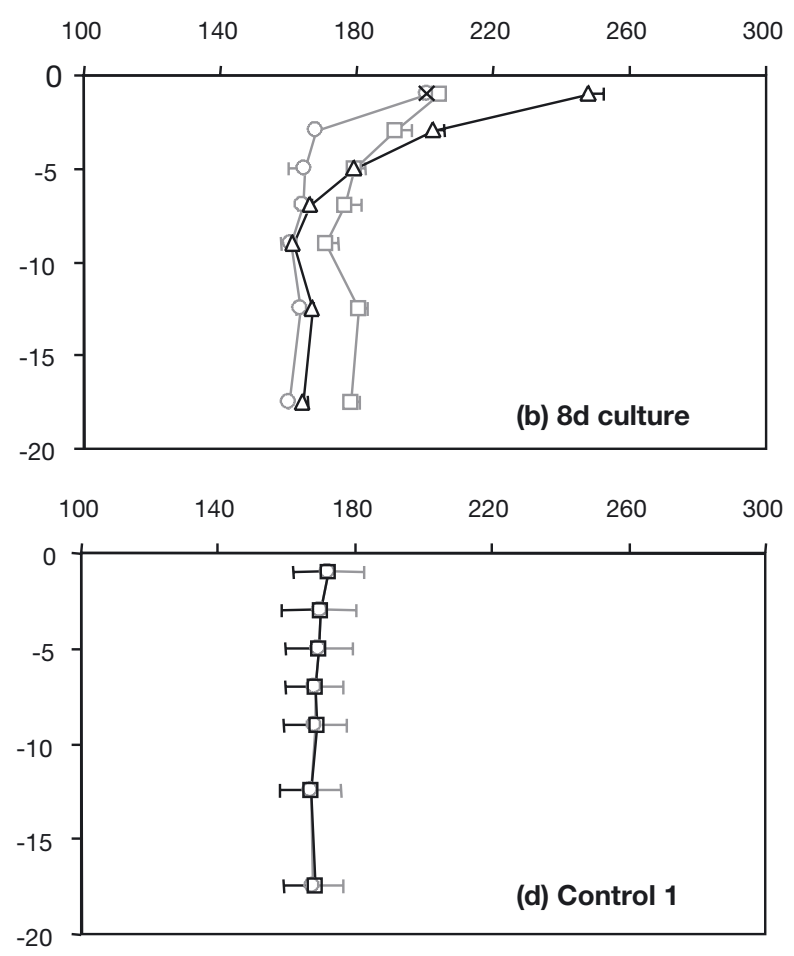

Fig. 2. Depth profiles of sediment water contents (averages and standard errors) after (a) 6, (b) 8 and (c) $11 \mathrm{~d}$ of diatom growth and for (d) Control 1 and (e) Control 2 performed without active diatoms. Symbols correspond to the same experiments as in Fig. 1

while, as expected, their chl a contents were slightly higher. As the cultures increased in age, the data scatter increased, probably due to spatial heterogeneity in the test bed and in the developing mat.

\section{Sediment resuspension}

In some situations (e.g. for fluid sediments), the distinction between biogenic fluff layer and bed erosion is very clear and apparent on a single erosion curve (see e.g. Orvain et al. 2003b). However, the succession in time of both erosion types is not always obtained in benthic flumes. Indeed, in the case of consolidated sediments, no bed erosion takes place because the maximal tested bed shear stresses are 
generally not high enough in flume devices to exceed the critical shear stress required for bed erosion. In such cases, only the biogenic fluff layer present at the sediment surface is resuspended, with very low values of eroded mass (the equivalent depth of sediment is typically less than $1 \mathrm{~mm}$ ). Visual observations are actually helpful in making clear statements about the erosion type. Type I erosion is a surface erosion of a deposited bed, whose critical shear stress depends on sediment characteristics (water content), and this erosion type is often followed by Type II erosion of dense bed at a greater depth, when shear stress increases. In the case of bed erosion (Type I and/or II in our experiments), big pieces of sediment are suddenly extracted from the deep layers of the sediment bed, while in the case of biogenic fluff layer erosion, only small aggregates of a very thin layer that is present at the surface are resuspended. This erosion type, related to bioturbation, is clearly different from Type I erosion. The tracks of snails that constitute a discrete fluff layer have a very specific eroding behaviour: the critical shear stress is always the same (ca. $0.015 \mathrm{~Pa}$ ), the resuspended mass decreases with time (as Type I erosion) and an inflexion occurs in the erosion curve if a dense bed is directly present under this thin discrete layer. Contrary to Type I erosion, resuspension fluxes of fluff layer erosion decrease when shear stress increases (Orvain et al. 2003b). In our case, the water contents were relatively low and no bed erosion (neither Type I nor Type II) took place except in 2 experiments that were performed with the oldest microphytobenthic mats (continuum between Type I and Type II erosion in Fig. 3d). The values of eroded sediment reached higher levels in these cases.

Except for the 2 experiments where general bed erosion (Type I and II) appeared (Fig. 3d), sediment resuspension always consisted of a biogenic layer erosion that began as soon as the critical shear stress (for biogenic erosion) had been exceeded. The critical shear stresses for biogenic layer erosion ranged over a small interval (i.e. $0.015 \pm 0.01 \mathrm{~Pa}$ ) for sediments with diatom cultures as well as in both controls (Fig. 3, Table 2). The erosion threshold of sediment (Table 2) was affected neither by the bioturbation by snails (2-way ANOVA, $F_{1,8}=0.275, \mathrm{p}>0.05$ ), nor by the age of the microphytobenthic biofilms (2-way ANOVA, $F_{3,8}=$ 0.702, p > 0.05).

Snail density and water content both affected the erosion kinetics of both types of sediment controls (Fig. 3e,f). The values of resuspended sediment mass were higher with bioturbation than without at all tested shear stresses, and the maximum eroded masses (i.e. measured at the maximum bed shear stress of 1.6 Pa) under Control 1 conditions were about $7 \mathrm{~g} \mathrm{~m}^{-2}$ with snails and about $1 \mathrm{~g} \mathrm{~m}^{-2}$ without (Fig. 3e). Maximum eroded masses under Control 2 conditions were about $12 \mathrm{~g} \mathrm{~m}^{-2}$ and $4 \mathrm{~g} \mathrm{~m}^{-2}$ with and without snails, respectively (Fig. 3f). Higher levels of eroded mass were also obtained in relation to water content differences under Control 2 conditions (Fig. 2d,e).

The values of resuspended sediment mass increased with the age of the microphytobenthic mat on all tested bed shear stresses. The scatter in resuspension curves between replicated experiments also increased with the age of the microphytobenthic mats (Fig. 3). For instance, maximum eroded masses were about 6,12 and $45 \mathrm{~g} \mathrm{~m}^{-2}$ at the bed shear stress of $1.6 \mathrm{~Pa}$, and the minimum values at the same bed shear stress were ca. 1,1 and $4 \mathrm{~g} \mathrm{~m}^{-2}$ for $6 \mathrm{~d}, 8 \mathrm{~d}$ and $11 \mathrm{~d}$ cultured sediments, respectively. The maximum amounts of erosion were measured from the $11 \mathrm{~d}$ test beds, where the mat became partly detached in the mesocosm, and these are the 2 experiments for which bed erosion (Type I and/or Type II) occurred (Fig. 3d).

The presence of a well-developed microphytobenthic mat is indicated by a change in sediment colour and the presence of gas bubbles. The densest mats were characterised by an apparent increase in bed roughness, where the mat developed with small bumps and holes that could be pierced by gas bubbles. At this point, portions of the mat sometimes detached during the simulated high tide in the mesocosm, partly exposing the underlying sediment. This is what was observed in the $11 \mathrm{~d}$ experiments shown in Fig. 3d; the sediments underwent bed erosion: pits appeared very rapidly in some places where the mat was disrupted and these became deeper and wider as shear stress was increased. In this case, the erosion changed from Type I to Type II erosion and the data suggests a continuum, eroding to greater depth as bed shear stress increases. It is difficult to state from the curve when erosion changed from Type I to Type II erosion.

In the absence of snail bioturbation and bed erosion, low amounts of resuspended sediment were measured for all tested shear stresses (for instance, the maximum eroded mass was about $4 \mathrm{~g} \mathrm{~m}^{-2}$ ), consistent with a high degree of stability for the sediment test beds. However, 1 of the $8 \mathrm{~d}$ test beds exhibited a relatively high amount of resuspended sediment mass, in the absence of a snail population, with a maximum eroded mass of about $12 \mathrm{~g} \mathrm{~m}^{-2}$ (square symbols in Fig. 3b). This experiment was performed with a sediment bed that had high water content throughout the sediment depth (see Fig. 2B). This example emphasises the role of the water content in the control of the biogenic layer erosion fluxes (but not the critical shear stress).

When sediment conditions varied within a narrow range of relatively low sediment water content (Fig. 2a, circles and triangles in Fig. 2c, circles and crosses in 

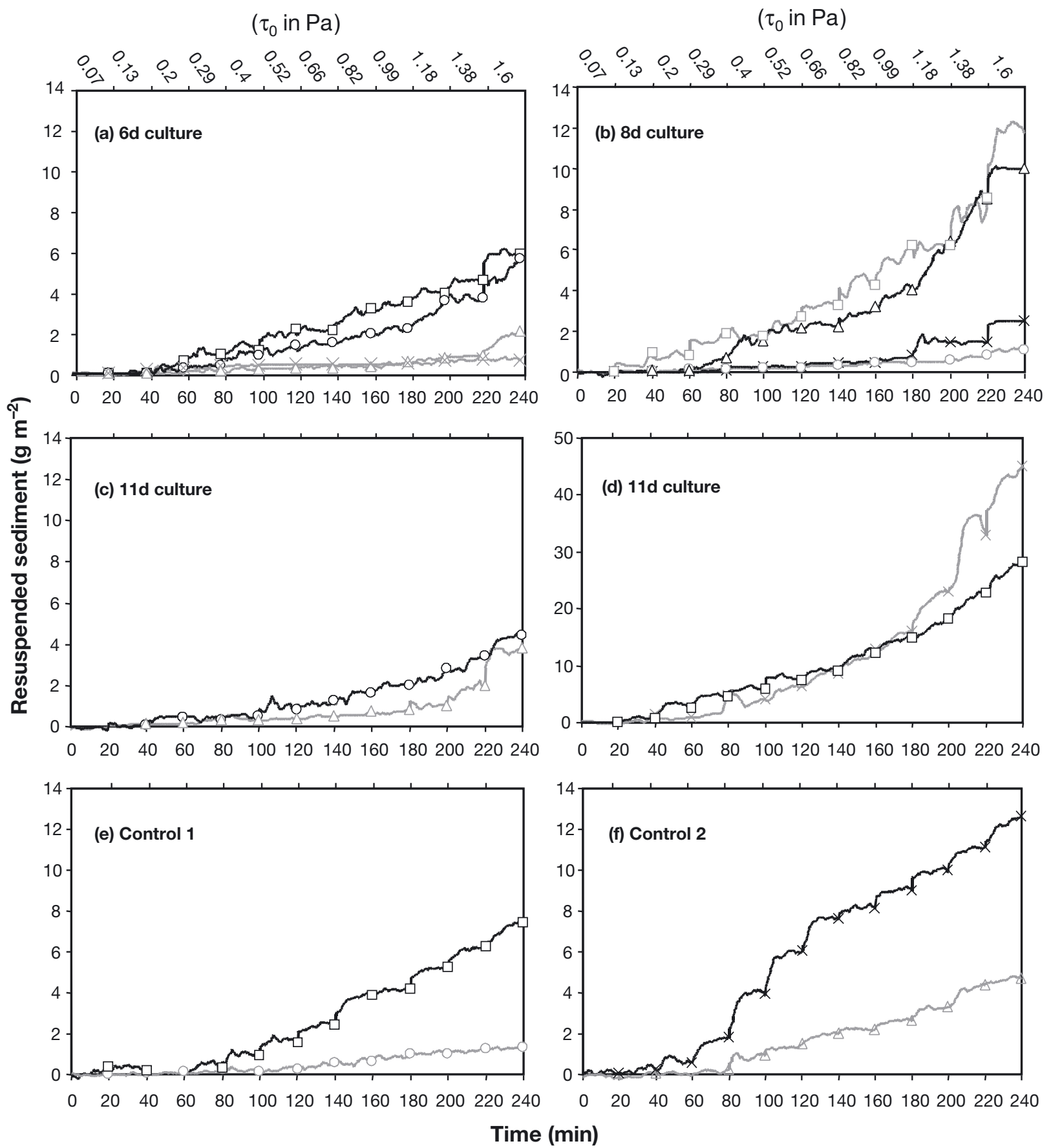

Fig. 3. Sediment resuspension with and without Hydrobia ulvae bioturbation (in black and grey, respectively) after (a) 6, (b) 8 and (c, d) $11 \mathrm{~d}$ of diatom growth and for (e) Control 1 and (f) Control 2 without diatoms. The $11 \mathrm{~d}$ culture experiments were separated into 2 pools: (c) those displaying fluff layer erosion and (d) those displaying Type I bed erosion (note the greater $y$-axis scale). Symbols correspond to the same experiments as in Fig. 1

Fig. 2b), only a biogenic fluff layer was eroded and, in this case, experiments with bioturbating snails showed a higher mass of eroded sediment than those performed without snails at each tested shear stress (Fig. 3a-c). For the 6 d cultured sediments (Fig. 3a), the scatter was very low between replicates and the effect of snail bioturbation on sediment resuspension was very clear and positive. These test bed data also had very low scatter compared to the other experiments (Figs. $1 \& 2$, Table 1).

Further analysis of erosion kinetics was conducted by using a model describing biogenic fluff layer ero- 
sion. Such an approach allowed us to examine and summarise the multiple benthic interactions controlling biogenic layer resuspension. This analysis is described in the subsequent section.

\section{Modelling resuspension results}

During flume experiments, Orvain et al. (2003b) observed the resuspension of a biogenic fluff layer in response to Hydrobia ulvae crawling activities on consolidated and fluid sediments. Concerning the biogenic layer erosion in question, this paper described a low erosion of non-biogenic aggregates (i.e. fluff layer not due to bioturbation) in control experiments without $H$. ulvae. When the snails bulldozed the sediment during crawling activities, some pieces of sediment were displaced and constituted the main part of the fluff layer, which was disconnected from the bed and easily eroded at low bed shear stress. The same phenomenon (fluff layer erosion) was observed in the present study and a similar erosion pattern was obtained with a constant critical threshold and a progressive erosion of the fluff layer. We thus tested the model, which was specifically developed by Orvain et al. (2003b) to reproduce, through simulation, such a fluff layer resuspension. This model is appropriate to describe the resuspension data of the 14 experiments, for which only fluff layer erosion was observed (Figs. $3 a-c, e, f)$.

Within the model, there is a relationship between the erosion rate and the quantity of sediment in the fluff layer that remains on the sediment bed during the process of erosion, $A_{t}\left(\mathrm{~kg} \mathrm{~m}^{-2}\right)$ according to:

Table 2. Summary of critical shear velocities $\left(u^{*}{ }_{\text {cr }}\right.$ obtained by analysis of the relationship between the concentration of suspended matter and shear velocity)

\begin{tabular}{|c|c|c|}
\hline Conditions & $\begin{array}{c}u_{\mathrm{cr}}^{*}(\mathrm{chl} a) \\
\left(\mathrm{m} \mathrm{s}^{-1}\right)\end{array}$ & $\begin{array}{l}u^{*}{ }_{c r}(\text { sedi- } \\
\text { ment) }\left(\mathrm{m} \mathrm{s}^{-1}\right)\end{array}$ \\
\hline \multirow[t]{2}{*}{$6 \mathrm{~d}$ of diatom growth and without Hydrobia ulvae } & 0 & 0.0148 \\
\hline & 0 & 0.0009 \\
\hline \multirow{2}{*}{$6 \mathrm{~d}$ of diatom growth and with Hydrobia ulvae } & 0.0069 & 0.0130 \\
\hline & 0.0017 & 0.0112 \\
\hline \multirow[t]{2}{*}{$8 \mathrm{~d}$ of diatom growth and without Hydrobia ulvae } & 0.0113 & 0.0117 \\
\hline & 0.0055 & 0.0121 \\
\hline \multirow[t]{2}{*}{$8 \mathrm{~d}$ of diatom growth and with Hydrobia ulvae } & 0.0053 & 0.0147 \\
\hline & 0.0098 & 0.0138 \\
\hline \multirow[t]{2}{*}{$11 \mathrm{~d}$ of diatom growth and without Hydrobia ulvae } & 0.0072 & 0.0143 \\
\hline & 0.0136 & 0.0138 \\
\hline \multirow[t]{2}{*}{$11 \mathrm{~d}$ of diatom growth and with Hydrobia ulvae } & 0.0100 & 0.0138 \\
\hline & 0.0094 & 0.0133 \\
\hline \multirow[t]{2}{*}{ Without diatom and without Hydrobia ulvae } & 0.0108 & 0.0124 \\
\hline & 0 & 0.0131 \\
\hline \multirow[t]{2}{*}{ Without diatoms and with Hydrobia ulvae } & 0.0111 & 0.0129 \\
\hline & 0.0091 & 0.0104 \\
\hline
\end{tabular}

$$
E_{\text {fluff }}=\alpha A_{t}\left(\frac{\tau_{0}}{\tau_{\text {fluff }}}-1\right) \text {, when }\left(\tau_{0}>\tau_{\text {fluff }}\right)
$$

else $E_{\text {fluff }}=0$

where $E_{\text {fluff }}$ is the erosion flux $\left(\mathrm{kg} \mathrm{m}^{-2} \cdot \mathrm{s}^{-1}\right), \alpha$ is an erosion coefficient $\left(\mathrm{s}^{-1}\right)$ and $\left(\tau / \tau_{\text {fluff }}-1\right)$ represents the excess shear stress. Initially, $A_{t=0}$ is the quantity of sediment in the fluff layer produced during the $6 \mathrm{~h}$ simulated low tide and this quantity varies in time during erosion as follows:

$$
\frac{\mathrm{d} A_{t}}{\mathrm{~d} t}=-E_{\text {fluff }}
$$

Before resuspension takes place, $A_{t}=A_{t=0}$ and the critical shear stress is fixed at a constant value ( $\left.\tau_{\text {fluff }}{ }^{\text {up }}\right)$. This parameter then evolves during the erosion process according to a relative gradient whose magnitude is expressed by $\delta$ (in Pa) as follows:

$$
\tau_{\text {fluff }}=\tau_{\text {fluff }}^{\text {up }}+\delta\left(\frac{A_{t=0}-A_{t}}{A_{t=0}}\right)
$$

Erosion rates actually depend on the initial mass of sediment in the fluff layer (i.e. the parameter $A_{t=0}$ in the model). In other words, $A_{t=0}$ is also a parameter which directly relates to the averaged erosion rate. This parameter is theoretically equivalent to the mass of sediment in the fluff layer, which is the result of bioturbatory activities (mucus, track and biodeposit production) at the end of the artificial low-tide period ( $t=0$ means that this is the beginning of the step-by-step increase in bed shear stress). The mass of sediment in fluff layer $\left(A_{t}\right)$ then decreases with time due to erosion, and erosion rates decrease in return. Finally, obtaining the 14 values of $A_{t=0}$ by minimisation tests ( 1 value for each resuspension curve) is a very convenient way to summarise all the information gained by resuspension curves and to examine how all factors interact to control the fluff layer resuspension.

We tested the suitability of the model for simulating the erosion kinetics of the experiments in which an initial resuspension of solids (fluff layer) was observed, i.e. all experiments except 2 from the $11 \mathrm{~d}$ cultured sediments (Fig. 3d). Common values of the $E_{0}$ and $\delta$ parameters and 14 separate values of $A_{t=0}$ parameter (1 for each curve) were identified by minimisation of the ordinary least squares (OLS) criterion, using a direct search (simplex of Nelder \& Mead 1965). We always obtained good simulations of erosion kinetics with a total $\mathrm{r}^{2}$ of $0.982\left(F_{1,13338}=364899\right.$, $\mathrm{p}<0.001)$, when comparing the 
computed to observed data. In contrast, equations for Type I or Type II bed erosion (e.g. Mehta et al. 1982) fitted less well to the experimental data. This result warrants the choice of model that we have made. The model was developed precisely to describe the fluff layer erosion as observed during experiments. Therefore, the differences in the amount of sediment mass available for resuspension in the fluff layer (i.e. $A_{t=0}$ ) accounted for most of the observed variations in erosion kinetics between the 14 simulated experiments.

The $A_{t=0}$ estimate decreased exponentially with dry density and chl a concentration. The best agreement between computed and experimental results was obtained with a negative power relationship between $A_{t=0}$ estimates and the measured sediment variables. On the other hand, snail bioturbation seemed to positively influence $A_{t=0}$ estimates (Fig. 4). Since the parameter $A_{t=0}$ depends on snail density ( $\mathrm{n}$ in ind. $\mathrm{m}^{-2}$ ) (Orvain et al. 2003b), we simulated the snail effect by simultaneously accounting for the negative exponential effects of other sediment variables $(X)$ as follows:

$$
A_{t=0}=a X^{b}\left(1-\mathrm{e}^{-v n+\beta}\right)
$$

where $v\left(\right.$ in $^{2}$ ) is a snail density-dependence parameter and $a$ (in $\mathrm{kg} \mathrm{m}^{-2}$ ), $b$ and $\beta$ are sediment-dependence parameters.

This equation has the advantage of expressing a negative dependence on the sediment variables even if the snail density is negligible. Among the tested sediment variables $(X)$ were: dry density (in $\mathrm{gDW}^{-1}$ ), EPS

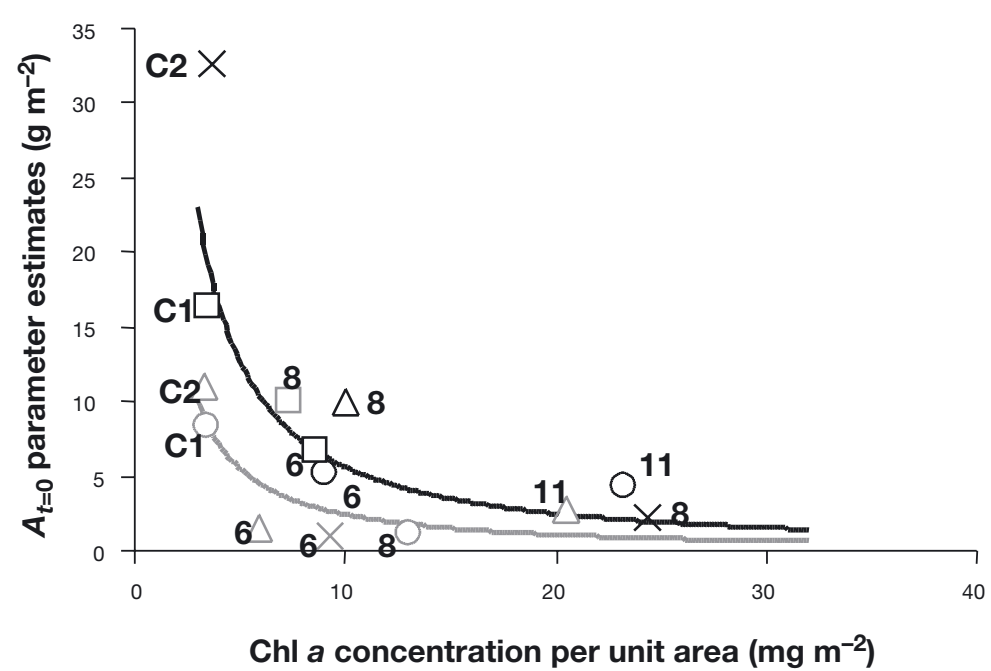

Fig. 4. Estimates of the $A_{t=0}$ parameter (i.e. the amount of sediment in the fluff layer) with and without snails (black and grey symbols, respectively). Lines represent the minimised relationship (Eq. 11) between these estimates and sediment surface (section $0-2 \mathrm{~mm}$ ) chl a concentrations per unit area $\left(\mathrm{mg} \mathrm{m}^{-2}\right)$ with and without Hydrobia ulvae bioturbation (black and grey lines, respectively). Symbols correspond to the same experiments as in Fig. 1 contents (in $\mathrm{mg} \mathrm{gDW}^{-1}$ ), chl $a$, phaeopigment and total pigment contents (in $\mu \mathrm{g} \mathrm{gDW}^{-1}$ ), chl $a$, phaeopigment and total pigment concentrations per unit area expressed in $\mathrm{mg} \mathrm{m}^{-2}$ (i.e. the product of the pigment variable in $\mu \mathrm{g} \mathrm{gDW}^{-1}$, the dry density in $\mathrm{gDW}^{-1}$ and the sampling depth of $0.002 \mathrm{~m}$ ). The strongest adjustment was obtained with chl a concentration per unit area $\left(\mathrm{r}^{2}=0.825, F_{1,13338}=63105, \mathrm{p}<0.001\right.$, Fig. 4). This result means that both dry density and chl a contents were required in the model as individual criteria (the chl a concentration), even though there was evidence of co-linearity between them. A weaker fit was obtained without snails than with, and it was necessary to choose the $A_{t=0}$ estimates with and without snails to improve the fit (Fig. 4); the goodness-of-fit was diminished when the parameter $v$ was $0\left(r^{2}=0.674\right)$. Finally, the best-adjusted model was:

$$
A_{t=0}=203700 \times[\mathrm{chla}]^{-1.17} \times\left(1-\mathrm{e}^{-6.10 \times 10^{-5} \mathrm{n}-0.30}\right)
$$

for an estimated $\alpha=7.71 \times 10^{-4} \mathrm{~s}^{-1}$ and $\delta=0.596 \mathrm{~Pa}$.

\section{Pigment resuspension}

The erosion thresholds of pigment $(0.068 \pm 0.056 \mathrm{~Pa}$, see Table 2) were significantly lower than those of the sediment (3-way ANOVA, $F_{1,23}=18.05, \mathrm{p}<0.001$ ). Differences between the erosion thresholds of sediment and pigment were related to the age of the microphytobenthic mats ( 3 -way ANOVA, $F_{3,23}=4.04, \mathrm{p}=$ 0.019 ) but not to the bioturbation by snails (3way ANOVA, $F_{1,23}=1.33, p>0.05$ ). The mass of resuspended pigment partially reflected the general pattern of resuspended sediments (Fig. 5), as the current increased in the flume, the amount of pigment resuspended increases. As expected, the lowest pigment fluxes were obtained in Control 1. Variability in the pattern of pigment resuspension increased with culture age, although a high level of correlation was found between resuspended sediment and pigment mass within separate experiments, the relation was different in each experiment (ANCOVA comparing pigment versus sediment mass eroded in each experiment, $F_{11,261}=162.53$, $\mathrm{p}<0.001$ ).

A partially hierarchical ANOVA, performed on log-transformed pigment content, shows that the single effects of 'bioturbation' and 'culture age' were not significant, but the interaction between 'bioturbation', 'culture age' and 'shear velocity' was significant (Table 3). This indicates that the effects of bioturbation on pigment kinetics were regu- 

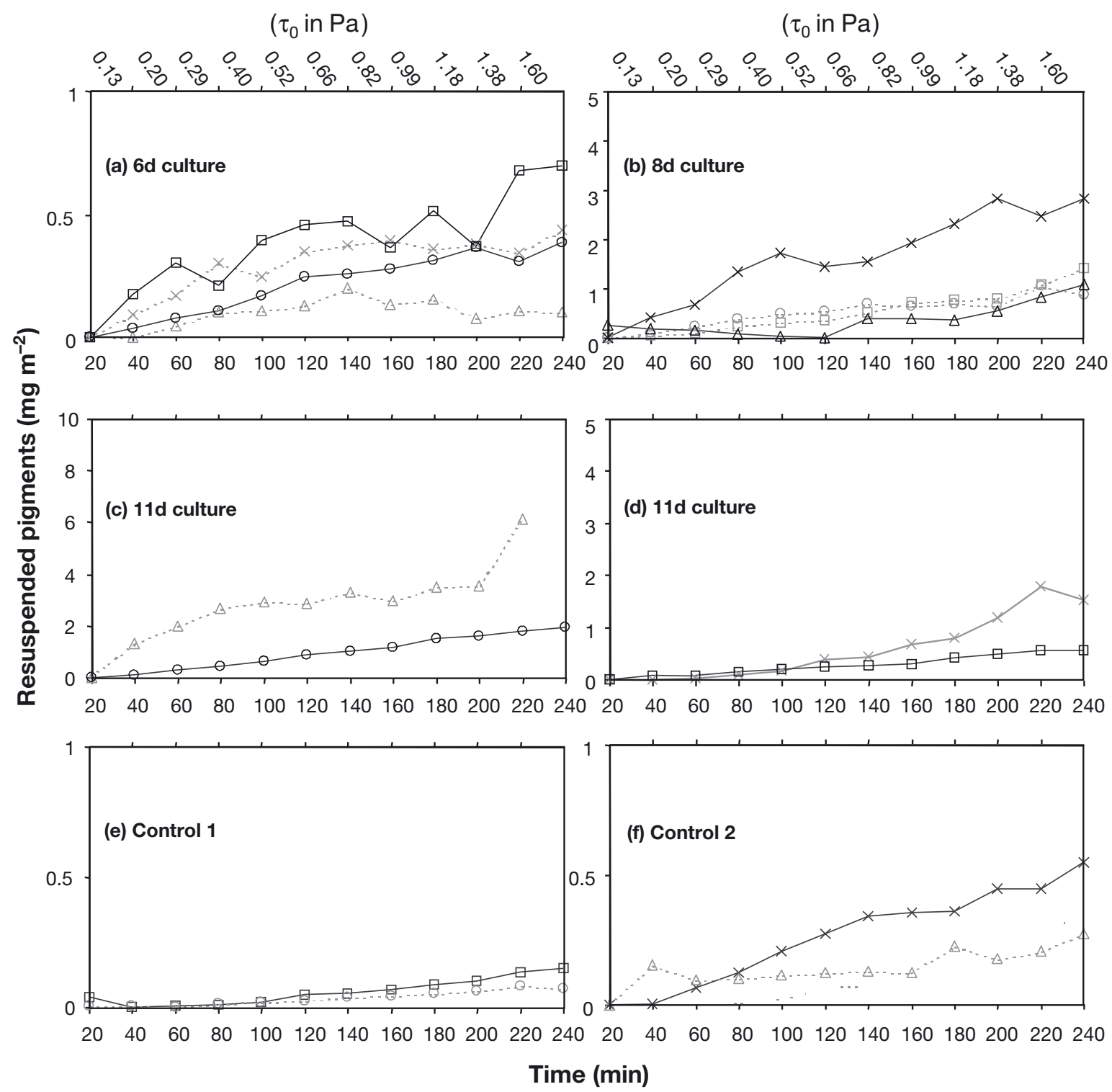

Fig. 5. Chloropigment resuspension with and without Hydrobia ulvae bioturbation (in black and grey, respectively) after (a) 6 , (b) 8 and (c, d) $11 \mathrm{~d}$ of diatom growth and (e) Control 1 and (f) Control 2 performed without diatoms. The $11 \mathrm{~d}$ culture experiments were separated into 2 pools: (c) those displaying fluff layer erosion and (d) those displaying Type I bed erosion. Symbols correspond to the same experiments as in Fig. 1

lated by the effects of the age of the microphytobenthic mats. For each culture age of the biofilm $(6 \mathrm{~d}, 8 \mathrm{~d}, 11 \mathrm{~d}$ and controls), split-plot ANOVA was therefore performed to determine in which cases pigment kinetics were modified by bioturbation (Table 4). The influence of snails on pigment resuspension was significant for 6 d cultured sediments (Table 4, Fig. 5a) and controls (Table 4, Fig. 5e,f). For each experiment, we analysed pigment resuspension by fitting linear curves to measured relationships between pigment $\left(\mathrm{g} \mathrm{m}^{-3}\right)$ and suspended particle matter $\left(\mathrm{kg} \mathrm{m}^{-3}\right)$ in water and calculate the slopes. The evolution of $[\mathrm{Chla:SPM}]_{\text {WATER }}$ ratios (i.e. the slopes in $\mu \mathrm{g} \mathrm{g}^{-1}$, which is the unit of chl a content) followed a log pattern as a function of 'culture age' (Fig. 6). Bioturbation by snails increased the proportion of algal material during the initial stages of erosion in the controls and in the $6 \mathrm{~d}$ cultured sediments (Fig. 6). Scatter was large between replicates of the $8 \mathrm{~d}$ cultured sediment beds and the highest ratio value was obtained in one experiment with snails. A similar average ratio and scatter were measured for the $11 \mathrm{~d}$ cultured sediments. In this case, bioturbation effects appeared to be totally obscured by the maturation of the diatom cultures. 
Table 3. Partially hierarchical ANOVA on log-transformed pigment concentration and performed on the whole set of data. The flume experiment factor is random, assuming that the main factors and their interactions ('bioturbation' and 'culture age') were tested over the flume experiment variability

\begin{tabular}{|lc|}
\hline Source of variation & \multicolumn{1}{c|}{ Statistics } \\
\hline Bioturbation & $\mathrm{p}=0.93 ; F_{1,8}=0.01$ \\
Culture age & $\mathrm{p}=0.11 ; F_{3,8}=2.73$ \\
Bioturbation $\times$ Culture age & $\mathrm{p}=0.56 ; F_{3,8}=0.73$ \\
$\begin{array}{l}\text { Flume run } \\
\quad \text { Bioturbation }- \text { Culture age) }\end{array}$ & $\mathrm{p}<0.01 ; F_{8,280}=112.83$ \\
$\begin{array}{l}\text { Shear velocity } \\
\text { Bioturbation } \times \text { Shear velocity }\end{array}$ & $\mathrm{p}<0.01 ; F_{11,280}=50.11$ \\
$\begin{array}{l}\text { Culture age } \times \text { Shear velocity } \\
\text { Bioturbation } \times \text { Culture age }\end{array}$ & $\mathrm{p}<0.815 ; F_{11,280}=0.62$ \\
$\quad \times$ Shear velocity & $\mathrm{p}=0.01 ; F_{33,280}=9.63$ \\
\end{tabular}

\section{DISCUSSION}

\section{Modelling the interacting effects of microphytobenthic mat and bioturbation on biogenic fluff layer erosion}

Bulk sediment erosion is preceded by the resuspension of the biogenic fluff layer, a layer of loosely aggregated, low-density particles, which may accumulate at the sediment-water interface through biologicallymediated processes. The resuspension of this biogenic fluff layer is therefore a factor in understanding the relative erodability of the sediment-water interface (Amos et al. 1997). Orvain et al. (2003b) proposed a model that simulates the initial resuspension of a biogenic fluff layer followed by that of the bed of bulk sediments. Until now, the model has used macrofauna density and sediment bulk density to assess the resuspension results.

The present study demonstrates that the presence of a microphytobenthic mat is another factor affecting erosion rates during the initial stages of erosion (fluff layer erosion). Indeed, it was necessary to incorporate chl a content as a new variable into the model to explain the variation in erosion rates (Eq. 11). In this equation, the effects of both microphytobenthic cultures and dry density were combined into a single criterion, the chl a content per unit area expressed in $\mathrm{mg} \mathrm{m}^{-2}$. This result means that a very low quantity of material was resuspended in the presence of a microphytobenthic mat. This pattern was described by an exponential decrease when the eroded mass was plotted against chl a content (Fig. 4). Generally, high water content and the presence of snails increased the quantity of eroded sediment over the measured chl a gradient. Bioturbation effects became obscured when senescence of the mat allowed bulk erosion to occur (Fig. 3d).

The present study also shows that the main factor determining the quantity and erosion rate of a fluff layer was the bioturbation exerted by snails, and this influence was probably mediated by crawling activity. Orvain \& Sauriau (2002) have found that Hydrobia ulvae crawling activities are positively influenced by chl a contents within the range of 1 to $15 \mu \mathrm{g} \mathrm{g}{ }^{-1}$. Conversely, Forbes \& Lopez (1986) observed a decrease in crawling rates with chl a contents within the range of 51 to $108 \mathrm{\mu g} \mathrm{g}^{-1}$ for $H$. truncata. Although our values of uppermost chl a content remained below a maximum value of ca. $31 \mathrm{\mu g} \mathrm{g}^{-1}$ (see Table 1), diatom mats were clearly established in our experiments and the local content at the sediment-water interface might have been closer to those reported by Forbes \& Lopez (1986). The decrease in the amount of resuspended material could thus be ascribed to a decrease in snail crawling activity when a dense microphytobenthic mat was present. Furthermore, our results are in agreement with the findings of Orvain et al. (2003b), who found that the increase in the amount of sediment in the biogenic fluff layer with water content is mediated by an increase in snail crawling activity. The present study, especially the modelling section, reveals the necessity to improve the model by taking into account

Table 4. Split-plot ANOVA on log-transformed pigment concentration performed on the 4 separate data sets of culture age. The flume experiment factor is random, assuming that the main factor ('bioturbation') has to be tested over the flume experiment variability

\begin{tabular}{|c|c|c|c|c|}
\hline $\begin{array}{l}\text { Source of } \\
\text { variation }\end{array}$ & $\begin{array}{l}\text { Control } \\
\text { sediments }\end{array}$ & $\begin{array}{l}6 \mathrm{~d} \text { cultured } \\
\text { sediments }\end{array}$ & $\begin{array}{l}8 \mathrm{~d} \text { cultured } \\
\text { sediments }\end{array}$ & $\begin{array}{l}11 \mathrm{~d} \text { cultured } \\
\text { sediments }\end{array}$ \\
\hline Bioturbation & $\mathrm{p}=0.54 ; F_{1,2}=0.55$ & $\mathrm{p}=0.49 ; F_{1,2}=0.71$ & $\mathrm{p}=0.56 ; F_{1,2}=0.49$ & $\mathrm{p}=0.53 ; F_{1,2}=0.56$ \\
\hline $\begin{array}{l}\text { Flume run } \\
\text { (Bioturbation) }\end{array}$ & $\mathrm{p}<0.01 ; F_{2,70}=138.2$ & $\mathrm{p}<0.01 ; F_{2,70}=94.29$ & $\mathrm{p}<0.01 ; F_{2,70}=67.48$ & $\mathrm{p}<0.01 ; F_{2,70}=143.86$ \\
\hline Shear velocity & $\mathrm{p}<0.01 ; F_{11,70}=12.73$ & $\mathrm{p}<0.01 ; F_{11,70}=26.44$ & $\mathrm{p}<0.01 ; F_{11,70}=12.88$ & $\mathrm{p}<0.01 ; F_{11,70}=24.45$ \\
\hline $\begin{array}{l}\text { Bioturbation } \times \\
\text { Shear velocity }\end{array}$ & $\mathrm{p}<0.01 ; F_{11,70}=2.82$ & $\mathrm{p}<0.01 ; F_{11,70}=3.58$ & $\mathrm{p}=0.917 ; F_{11,70}=0.47$ & $\mathrm{p}=0.05 ; F_{11,70}=1.95$ \\
\hline
\end{tabular}




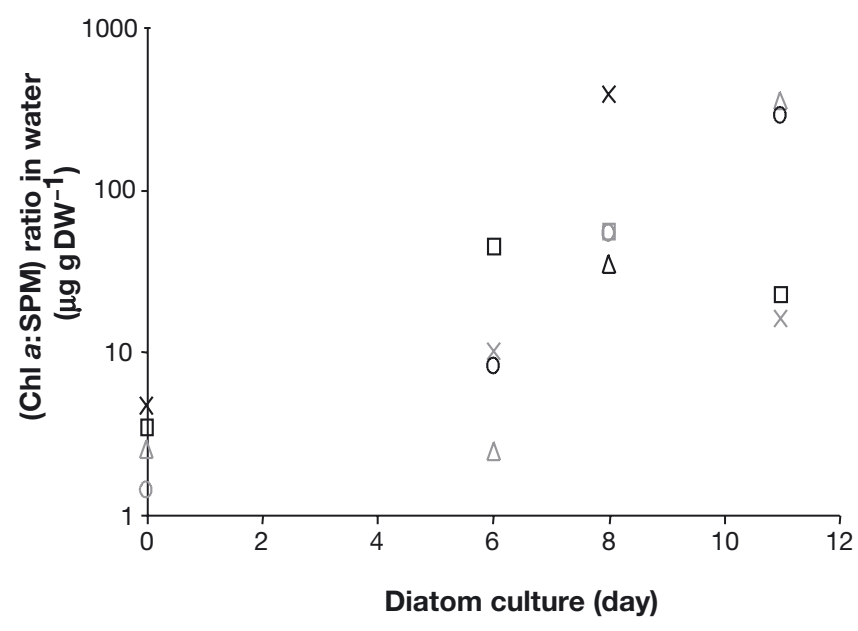

Fig. 6. Relationship between [Chla:SPM] $]_{\text {WATER }}$ and culture age with or without snails (black and grey symbols, respectively). Symbols correspond to the same experiments as in Fig. 1

the effect of microphytobenthos on the rates of fluff layer erosion. Using this information, we will attempt to further relate the interacting effects of microphytobenthos and bioturbation by $H$. ulvae to their effects on crawling activity through new experiments and/or model developments (Orvain \& Sauriau 2002).

Microphytobenthos biomass and dry density actually appeared as secondary factors having a regulating influence on fluff layer formation and indirectly reflecting the age of the diatom culture. Indeed, sediments containing the oldest diatom cultures were both the most chl $a$ enriched and had the most water-rich sediments (Figs. 1c \& 2c). Nonetheless, both factors are also implicated in controlling the behaviour and critical shear stress of bed erosion (see above), and grazing pressure exerted by Hydrobia ulvae may limit chl a development and its potential influence on general bed erosion (Austen et al. 1999). However, bioturbation by snails does not seem to be a factor affecting bed erosion since no snail effects can be distinguished in our results (Fig. 3c,d). We obtained a stimulation of microphytobenthos development mediated by bioturbation processes, rather than any limiting effect of grazing on diatom growth.

\section{Physiological state of microphytobenthic mat con- trolling bed erosion}

The longer the diatom cultures were allowed to grow, the greater the scatter, in terms of sediment water and chl a contents, between replicated experiments (Figs. $1 \& 2$ ). This led to the large variations in resuspension that we observed for the oldest mats (Fig. 3). Our results confirm that the stationary and senescent phases are both characterised by EPS enrichment. However, the limit between these phases could not be predicted. The appearance of a senescent phase should be related to bacteria population (Yallop et al. 2000) and preferably correlated to EDTAextractable carbohydrates rather than waterextractable ones (Underwood et al. 1995, de Winder et al. 1999, de Brouwer \& Stal 2001).

High EPS concentrations tend to stabilise sediment surfaces (Sutherland et al. 1998b). However, increases in bed roughness and water contents, which are other consequences of mat development (Paterson et al. 2000, Decho 1990, Orvain et al. 2003a), rendered the mat more fragile. Our results suggest a balance between stabilising and destabilising factors during stationary/senescent phases. At this time the mat could be either stable or unstable (Fig. 3c,d, respectively), and thus modify the conditions for the 'threshold effects' that are inevitably associated with erosion features. The stationary phase might be characterised by stable sediments while the senescent phase might be characterised by bed erosion with typically high erosion rates, but new experiments must be performed to differentiate between these phases in terms of resuspension.

The relative destabilising effects of a diatom mat during the stationary/senescent phase were not reported by Sutherland et al. (1998b), who noted during similar laboratory experiments that this stage of mat development showed the highest sediment stability. However, they observed that the erosion of the diatom mat tightly controlled sediment erosion. Their sediment preparation was different from ours, since they simulated an alternating dark-light cycle over sediment beds, which remained uncovered by seawater. In their case, sediment water contents remained low even during stationary phases.

The erosion of the diatom mat during preliminary stages of the stationary phase was characterised by low eroded sediment mass but high quantities of resuspended chl a (e.g. Figs. 3c \& 4c). Once the mat had been disrupted in the senescent phase, the underlying layers, where water content increased during the mat growth, were suddenly subjected to high shear stresses and displayed bed erosion. Due to the low levels of vertical mixing in the mesocosm in our experiments, the deep layers did not become enriched in chl $a$ and the resuspended material was characterised by low chl a concentrations, but high SPM amounts (Figs. 3d \& 4d). Chl a content of cores taken from the field are often reported to be homogeneous in the top cm (Lucas \& Holligan 1999, Paterson et al. 2000), especially during dark periods (de Brouwer \& Stal 2001). 
Consequently, unlike our laboratory experiments, natural bed erosion should induce resuspension of high amounts of chl a along with the associated sedimentary material (Delgado et al. 1991, de Jonge \& van Beusekom 1995).

The positive influence of diatom mats on sediment water content could thus introduce a destabilising influence on diatom mats in sediments when the algal biomass reaches the senescent phase in laboratory experiments. Our results are thus not directly consistent with the theory of microphytobenthic biostabilisation. Diatom biomass is usually considered to be a primary cause of sediment stability since the cooccurrence of stable sediments and diatom mats has been reported in natural conditions (Underwood \& Paterson 1993, Sutherland et al. 1998a, b, de Winder et al. 1999, Widdows et al. 2000, Yallop et al. 2000, Andersen 2001). However, we may also interpret such levels of correlation by reversing the causes and the consequences: stable sediments can provide an habitat favouring microphytobenthic development. This also means that there would be a positive feedback between stabilising conditions (such as a decrease of current velocities or an increase in consolidation) and enhanced production of benthic diatoms.

The significant positive influence of microphytobenthos on sediment stability that has often been reported from in situ measurements might also be a consequence of the fact that natural controls on diatom populations force them to maintain exponential growth under natural conditions (Blanchard et al. 2001). These natural controls on diatom growth may include: (1) natural resuspension under the effect of tidal currents reinforced by wind-stress (de Jonge \& van Beusekom 1995), (2) grazing pressure induced by macrobenthic and meiobenthic populations, and (3) bioturbation phenomena (see below). We also obtained sediments in exponential growth which were very resistant to erosion, and the only resuspension which occurred in these was that of a fluff layer whose formation was mainly due to bioturbation by Hydrobia ulvae (Fig. 3a). The only differences between our results and in situ studies that show biostabilising effects of microphytobenthos could be ascribed to the lack of stationary/ senescent phase in the field.

How representative of natural conditions are the stationary/senescent phases we obtained during our experiments? The stationary growth phase observed in our laboratory experiments could be attained under the usual range of conditions encountered in the field. However, this event may be so episodic that it cannot be revealed by sporadic field studies. This also means that in situ field studies are unlikely to be carried out in regions where mats are in the senescent phase and show the concomitant increase in sediment erosion observed in our laboratory experiments. If a stationary/ senescent phase can really occur in the field, an associated enhanced erodability of the sediment should be demonstrated by long-term surveys, exhibiting the succession of (1) growth phases that are characterised by long series of oscillations in microphytobenthic biomass with net increases during daytime exposure and (2) bed erosion phases that we ascribe to the appearance of a stationary phase, as in our study. Indeed, long-term surveys of microphytobenthic biomass have usually exhibited diatom losses associated with resuspension events taking place after chl a peaks in the sediment bed (Underwood \& Paterson 1993, Blanchard et al. 2002). Although windinduced stress must be the prime factor controlling such bulk erosion, the physiological state can also be a factor responsible for the occurrence of bulk erosion in the field.

\section{Influences of Hydrobia ulvae bioturbation on pigment resuspension}

The sequential resuspension of organisms and sediment is a question of increasing interest for benthic ecologists (Blanchard et al. 1997, Lucas et al. 2000, 2001, Shimeta et al. 2002). The quantity of eroded chl a normalised to eroded sediment (i.e. [Chla:SPM] WATER ratio) were over 10 times greater than sediment chl a contents at the end of exponential growth or during stationary growth phases. During these periods, an active mat was visible at the sediment-water interface. Kelly et al. (2001) used cryolander techniques to analyse in detail the microscale variations within chl a vertical profiles taken in the field. They clearly showed that chl a contents varied significantly at sub-millimetre intervals where values were over 20 times greater in the cryolander $0.2 \mathrm{~mm}$ surface section than in the $5 \mathrm{~mm}$ surface section from classic-style cores. In the present study, the maximal depth of the resuspended layer was ca. $100 \mu \mathrm{m}$, which is close to the size of the theoretical photic zone (Kelly et al. 2001). Therefore, the chl a contents depended on the vertical resolution of our measurements and it was not surprising to obtain [Chla:SPM] WATER ratios over 10 times greater than chl a contents measured from coarse cores, even if the vertical resolution was relatively high in our depth profiles (i.e. $2 \mathrm{~mm}$ ).

Our results indicate that critical erosion thresholds of microphytobenthos are lower than those of sediments (Table 2). Generally, fluff layers are located within the photic zone where chl a enrichment is high in the presence of a mat. Since bioturbation was the major factor governing fluff layer resuspension, we can presume that the precocious resuspension of $\mathrm{chl} a$ is related to 
the influence of snails. Blanchard et al. (1997) obtained differing erosion thresholds when comparing microphytobenthos to bacteria erosion in bioturbated layers produced by Hydrobia ulvae. They concluded that microphytobenthos behaves actively within the eroded mucus matrix. However, our results suggest that the low critical thresholds of chl a are not due to the bioturbation by snails, but rather that they are typical of growing microphytobenthic mats.

Our results nevertheless emphasise significant effects of bioturbation by snails on pigment resuspension kinetics, and the enhancement of pigment resuspension by Hydrobia ulvae is clearly mediated by the age of the microphytobenthic mats. We found higher [Chla:SPM] WATER ratios with snails than without for controls and $6 \mathrm{~d}$ culture sediment, but not for sediments covered by the oldest microphytobenthic mats. These results support the theory that there are conditions stimulating diatom growth within the local environment of the fluff layer. The dislodging of sediment particles during grazing and bioturbation could encourage colonisation of bioturbated layers by diatoms; this phenomenon is likely to enhance diatom migration and/or production. This theory is supported by Levinton \& Lopez (1977), who developed a model predicting a carrying capacity of $H$. ulvae populations by considering high growth rates of microphytobenthic cells in snail faecal pellets. In this sense, macrofaunal contribution to the creation of the surface fluff layer provide a reasonable explanation for the enrichment in pigment during surface erosion in field settings (Wiltshire et al. 1998, Lucas et al. 2000).

By only considering experiments performed on the $6 \mathrm{~d}$ cultured sediments, the averaged [Chla:SPM] WATER increased by about 2.5 times in the presence of snails; the maximum amounts of resuspended sediments in these experiments were about $6 \mathrm{gDW} \mathrm{m}{ }^{-2}$ and $1 \mathrm{gDW}$ $\mathrm{m}^{-2}$ with and without snails, respectively. For a chl $a$ content equal to $8.95 \mathrm{\mu g} \mathrm{gDW}^{-1}$ in the $6 \mathrm{~d}$ cultured sediments (see Table 1), we can compute the mass of resuspended pigments as $\left(6 \mathrm{gDW} \mathrm{m}^{-2} \times 8.95 \mathrm{\mu g} \mathrm{g} \mathrm{DW}^{-1}\right.$ $\times 2.5)=134.25 \mathrm{\mu g} \mathrm{m}^{-2}$ with 10000 snails $\mathrm{m}^{-2}$, whereas this value only reaches $\left(1 \mathrm{~g} \mathrm{DW} \mathrm{m}^{-2} \times 8.95 \mu \mathrm{g} \mathrm{DW}^{-1)}=\right.$ $8.95 \mathrm{\mu g} \mathrm{m}^{-2}$ without snails. According to this calculation, pigment resuspension increased by 15 times due to snail bioturbation. This factor declined as the mats became older and when the effects of bioturbation were less definitive.

\section{CONCLUSIONS}

Natural resuspension of microphytobenthos from tidal flats has been shown to be associated with mud resuspension and to be affected by wind-induced waves (de Jonge \& van Beusekom 1995, Underwood \& Kromkamp 1999). In this context, there is evidence that surface erosion of microphytobenthic mats occurs as a short-term event during high tides (Grant et al. 1986, Lucas et al. 2000, Blanchard et al. 2002, Shimeta et al. 2002), in spite of the stabilising properties of the microphytobenthic mats. On a mudflat, the mats formed by microphytobenthic assemblages occur patchily (Decho 1990) and, within such a mosaic, the physiological state of the mat probably differs from one location to another (Yallop et al. 1994, van Duyl et al. 2000). Our results suggest that a spatially heterogeneous mat can result in large differences in the extent of sediment erosion. In areas where the mats are senescent, erosion may be enhanced, while little or no bed erosion occurs where the microphytobenthic assemblages are in an exponential growth phase. The addition of chl $a$ and sediment mass into the water column as a result of bed erosion produces peaks that could be reported as a reaction to wave-induced stress (de Jonge \& van Beusekom 1995, Shimeta et al. 2002). These peaks of resuspended microphytobenthos may actually be the sum of various local resuspension events and thus, to be compared with our experiments, should be averaged. The large scatter in resuspended sediment mass observed in our experiments with 'old' mats in a stationary/senescent phase suggest a solution to the paradox described by de Jonge \& van Beusekom (1995). They inferred that, when considering large areas, resuspended chl a does not reflect the stabilising actions exerted by microphytobenthic mats.

We assume that the initial stages of erosion, which are mainly related to bioturbation activities, also contribute to low upward fluxes of $\mathrm{chl} a$. In contrast to the peaks of chl a resuspended due to bed erosion, this second source of chl $a$ is likely to occur during every tidal cycle. The omnipresence of deposit-feeder species in estuarine and coastal systems (Herman et al. 1999) suggests that large areas of intertidal mudflats act as a source of chl a for the water column. Interestingly, the model for fluff layer erosion tested in this study can provide insights into the impact of fluff layer formation (in relation to bioturbation) on the microphytobenthic dynamics in the field. Finally, this study suggests that there are 2 ways for the microphytobenthos to become resuspended, depending on the growth phase of the mat: (1) In an exponential growth phase, the mats stabilise underlying sediment beds and macrofauna bioturbation contributes to chl a resuspension during fluff layer erosion, and (2) in a senescent phase, the increase in bed roughness and water contents renders the mat fragile and subject to the high erosion rates typical of bulk sediment erosion. 
Acknowledgements. The Regional Council of Poitou-Charentes and Ifremer supported this study with a doctoral grant awarded to F.O. We are grateful to Dr. A. Gangnery, Dr. S. Lefebvre and Prof. G. Blanchard for advice on the production of the manuscript. We would like to thank M. Prineau, M. Guillaut, M. Bréret and G. Guillou for assistance in the lab. Many thanks to J. Guarini for improving the English language. We also thank 3 anonymous referees who made helpful comments on earlier drafts.

\section{LITERATURE CITED}

Amos CL, Feeney T, Sutherland TF, Luternauer JL (1997) The stability of fine-grained sediments from the Fraser River Delta. Estuar Coast Shelf Sci 45:507-524

Andersen TJ (2001) Seasonal variation in erodability of two temperate, microtidal mudflats. Estuar Coast Shelf Sci 53: $1-12$

Andersen TJ, Jensen KT, Lund-Hansen L, Mouritsen KN, Pejrup M (2002) Enhanced erodability of fine-grained marine sediments by Hydrobia ulvae. J Sea Res 48: $51-58$

Austen I., Andersen TJ, Edelvang K (1999) The influence of benthic diatoms and invertebrates on the erodability of an intertidal mudflat, the Danish Wadden Sea. Estuar Coast Shelf Sci 49:99-111

Beaulieu SE (2002). Accumulation and fate of phytodetritus on the sea floor. Oceanogr Mar Biol Annu Rev 40:171-232

Bianchi TS, Dawson R, Sawangwong P (1988) The effects of macrobenthic deposit-feeding on the degradation of chloropigments in sandy sediments. J Exp Mar Biol Ecol 122:243-255

Blanchard GF, Sauriau PG, Cariou-Le Gall V, Gouleau D, Garet MJ, Olivier F (1997) Kinetics of tidal resuspension of microbiota: testing the effects of sediment cohesiveness and bioturbation using flume experiments. Mar Ecol Prog Ser 151:17-25

Blanchard GF, Guarini JM, Orvain F, Sauriau PG (2001) Dynamic behaviour of benthic microalgae biomass in intertidal mudflats. J Exp Mar Biol Ecol 264:85-100

Blanchard GF, Simon Bouhet B, Guarini JM (2002) Properties of the dynamics of intertidal microphytobenthic biomass. J Mar Biol Assoc UK 82:2017-1028

Davis WR (1993) The role of bioturbation in sediment resuspension and its interaction with physical shearing. J Exp Mar Biol Ecol 171:187-200

de Brouwer JFC, Stal LJ (2001) Short-term dynamics in microphytobenthos distribution and associated extracellular carbohydrates in surface sediments of an intertidal mudflat. Mar Ecol Prog Ser 218:33-44

Decho AW (1990) Microbial exopolymer secretions in ocean environments: their role(s) in food webs and marine processes. Oceanogr Mar Biol Annu Rev 28:73-153

de Jonge VN, van Beusekom JEE (1995) Wind- and tideinduced resuspension of sediment and microphytobenthos from tidal flats in the Ems estuary. Limnol Oceanogr 40: 766-778

Delgado M, de Jonge VN, Peletier H (1991) Experiments on resuspension of natural microphytobenthos populations. Mar Biol 108:321-328

de Winder B, Staats N, Stal LJ, Paterson DM (1999) Carbohydrate secretion by phototrophic communities in tidal sediments. J Sea Res 42:131-146

Dubois M, Gilles KA, Hamilton JK, Rebers PA, Smith F (1956) Colorimetric method for determination of sugars and related substances. Anal Chem 28:350-356
Forbes VE, Lopez GR (1986) Changes in feeding and crawling rates of Hydrobia truncata (Prosobranchia: Hydrobiidae) in response to sedimentary chlorophyll-a and recently egested sediment. Mar Ecol Prog Ser 33:287-294

Galois R, Blanchard G, Seguignes M, Huet V, Joassard L (2000) Spatial distribution of sediment particulate organic matter on two estuarine intertidal mudflats: a comparison between Marennes-Oléron Bay (France) and the Humber estuary (UK). Contin Shelf Res 20:1199-1217

Gouleau D, Jouanneau JM, Weber O, Sauriau PG (2000) Short- and long-term sedimentation on MontportailBrouage intertidal mudflat, Marennes-Oléron Bay (France). Contin Shelf Res 20:1513-1530

Grant J, Bathmann UV, Mills EL (1986) The interaction between benthic diatom films and sediment transport. Estuar Coast Shelf Sci 23:225-238

Grant WD, Boyer LF, Sanford LP (1982) The effects of bioturbation on the initiation of motion of intertidal sands. J Mar Res 40:659-677

Herman PMJ, Middelburg JJ, van de Koppel J, Heip CHR (1999) Ecology of estuarine macrobenthos. Adv Ecol Res 29:195-240

Herman PMJ, Middelburg JJ, Widdows J, Lucas CH, Heip CHR (2000) Stable isotopes as trophic tracers: combining field sampling and manipulative labelling of food resources for macrobenthos. Mar Ecol Prog Ser 204:79-92

Jensen KT, Siegismund HR (1980) The importance of diatoms and bacteria in the diet of Hydrobia-species. Ophelia 1: 193-199

Jumars PA, Nowell ARM (1984) Effects of benthos on sediment transport: difficulties with functional grouping. Contin Shelf Res 3:115-130

Kelly JAC, Honeywill C, Paterson DM (2001) Microscale analysis of chlorophyll-a in cohesive, intertidal sediments: the implications of microphytobenthos distribution. J Mar Biol Assoc UK 81:151-162

Levinton JS, Lopez GR (1977) A model of renewable resources and limitation of deposit-feeding benthic populations. Oecologia 31:177-190

Lorenzen C (1967) Determination of chlorophyll and phaeopigments spectrophotometric equations. Limnol Oceanogr 12:343-346

Lucas CH, Holligan PM (1999) Nature and ecological implications of algal pigment diversity on the Molenplaat tidal flat (Westerschelde estuary, SW Netherlands). Mar Ecol Prog Ser 180:51-64

Lucas $\mathrm{CH}$, Widdows J, Brinsley, MD, Salkeld PN, Herman PMJ (2000) Benthic-pelagic exchange of microalgae at a tidal flat. 1. Pigment analysis. Mar Ecol Prog Ser 196: $59-73$

Lucas CH, Banham C, Holligan PM (2001) Benthic-pelagic exchange of microalgae at a tidal flat. 2. Taxonomic analysis. Mar Ecol Prog Ser 212:39-52

Mehta AJ, Parchure, TM, Dixit JG, Ariathurai R (1982) Resuspension potential of deposited cohesive sediment beds. In: Kennedy VS (ed) Estuarine comparisons. Academic Press, New York, NY, p 591-608

Nelder JA, Mead R (1965) A simplex method for function minimization. Computer J 7:308-313

Orvain F, Sauriau PG (2002) Environmental and behavioural factors affecting activity in the intertidal gastropod Hydrobia ulvae. J Exp Mar Biol Ecol 272:191-216

Orvain F, Galois R, Barnard C, Sylvestre A, Blanchard G, Sauriau PG (2003a) Carbohydrate production in relation to microphytobenthic biofilm development: an integrated approach in a tidal mesocosm. Microb Ecol 45:237-251

Orvain F, Le Hir P, Sauriau PG (2003b) A model of fluff layer 
erosion and subsequent bed erosion in the presence of the bioturbator, Hydrobia ulvae. J Mar Res 61:823-851.

Paterson DM, Tolhurst TJ, Kelly JA, Honeywill C and 6 others (2000) Variations in sediment properties, Skeffling mudflat, Humber Estuary, UK. Contin Shelf Res 20:1373-1396

Potvin C (1993) ANOVA: experiments in controlled environments. In: Scheiner SM, Gurevitch J (eds) Design and analysis of ecological experiments. Chapman and Hall, London, p 46-68

Sauriau PG, Kang CK (2000) Stable isotope evidence of benthic microalgae-based growth and secondary production in the suspension feeder Cerastoderma edule (Mollusca, Bivalvia) in the Marennes-Oleron Bay. Hydrobiologia 440: 317-329

Shimeta J, Amos CL, Beaulieu SE, Ashiru OM (2002) Sequential resuspension of protists by accelerating tidal flow: implications for community structure in the benthic boundary layer. Limnol Oceanogr 47:1152-1164

Sutherland TF, Amos CL, Grant J (1998a) The effect of buoyant biofilms on the erodability of sublittoral sediments of a temperate microtidal estuary. Limnol Oceanogr 43: $225-235$

Sutherland TF, Grant J, Amos CL (1998b) The effect of carbohydrate production by the diatom Nitzschia curvilineata on the erodability of sediment. Limnol Oceanogr 43:65-72

Tolhurst TJ, Riethmüller R, Paterson DM (2000) In situ versus laboratory analysis of sediment stability from intertidal mudflats. Contin Shelf Res 20:1317-1334

Underwood GJC, Paterson DM (1993) Seasonal changes in diatom biomass, sediment stability and biogenic stabilization in the Severn Estuary. J Mar Biol Assoc UK 73: 871-887

Underwood GJC, Kromkamp J (1999) Primary production by phytoplankton and microphytobenthos in estuaries. Adv Ecol Res 29:93-153

Editorial responsibility: Otto Kinne (Editor),

Oldendorf/Luhe, Germany
Underwood GJC, Paterson DM, Parkes RJ (1995) The measurement of microbial carbohydrate exopolymers from intertidal sediments. Limnol Oceanogr 40:1243-1253

van Duyl FC, de Winder B, Kop AJ, Wollenzien U (2000) Consequences of diatom mat erosion for carbohydrate concentrations and heterotrophic bacterial activities in intertidal sediments of the Ems-Dollard estuary. Contin Shelf Res 20:1335-1349

von Ende CN (1993) Repeated measures analysis: growth and other time-dependent measures. In: Scheiner SM, Gurevitch J (eds) Design and analysis of ecological experiments. Chapman and Hall, London, p 113-137

Widdows JS, Brown S, Brinsley MD, Salkeld PN, Elliott M (2000) Temporal changes in intertidal sediment erodability: influence of biological and climatic factors. Contin Shelf Res 20:1275-1289

Willows RI, Widdows J, Wood RG (1998) Influence of an infaunal bivalve on the erosion of an intertidal cohesive sediment: a flume and modeling study. Limnol Oceanogr 43:1332-1343

Wiltshire KH, Tolhurst TJ, Paterson DM, Davidson I, Gust G (1998) Pigment fingerprints as markers of erosion and changes in cohesive sediment surface properties in simulated and natural erosion events. In: Black KS, Paterson DM, Cramp A (eds) Sedimentary processes in the intertidal zone. Geol Soc Lond Spec Publ 139. Geographical Society, London, p 99-114

Yallop ML, de Winder B, Paterson DM, Stal LJ (1994) Comparative structure, primary production and biogenic stabilization of cohesive and non-cohesive sediments inhabited by microphytobenthos. Estuar Coast Shelf Sci 39:565-582

Yallop ML, Paterson DM, Wellsbury P (2000) Interrelationships between rates of microbial production, exopolymer production, microbial biomass, and sediment stability in biofilms of intertidal sediments. Microb Ecol 39:116-127

Submitted: November 11, 2002; Accepted: April 8, 2004 Proofs received from author(s): August 18, 2004 